Fordham Law School

FLASH: The Fordham Law Archive of Scholarship and History

Faculty Scholarship

2020

Case-Linked Jurisdiction and Busybody States

Howard M. Erichson

John C.P. Goldberg

Benjamin Zipursky

Follow this and additional works at: https://ir.lawnet.fordham.edu/faculty_scholarship

Part of the Courts Commons, and the Supreme Court of the United States Commons 


\title{
Article
}

\section{Case-Linked Jurisdiction and Busybody States}

\author{
Howard M. Erichson, ${ }^{\dagger}$ John C.P. Goldberg, ${ }^{\dagger \dagger}$ and \\ Benjamin C. Zipursky ${ }^{\dagger \dagger}$
}

INTRODUCTION

A majority of the Justices of the United States Supreme Court seems to have decided, over the past decade, that the law of personal jurisdiction needs to be cleaned up. In cases addressing both general and specific personal jurisdiction, the Court has issued striking rebukes to lower courts for adopting too capacious a view of their authority to adjudicate claims against out-of-state defendants. ${ }^{1}$

In one area-general personal jurisdiction-the Court has adopted a bright line rule. General jurisdiction over a corporation exists only in a corporation's home state ${ }^{2}$ - essentially, its state of incorporation or principal place of business. ${ }^{3}$ All but Justice Sotomayor seem pleased with the categorical quality of the rule and its strong warning to aggressive forum shoppers and lower courts inclined to accommodate them. ${ }^{4}$

$†$ Professor of Law, Fordham University School of Law. Copyright (C) 2020 by Howard M. Erichson.

†† Deputy Dean and Carter Professor of General Jurisprudence, Harvard Law School. Copyright (C) 2020 by John C.P. Goldberg.

†† James H. Quinn '49 Chair in Legal Ethics and Professor of Law, Fordham University School of Law. The authors thank Pamela Bookman, Teddy Rave, Bill Rubenstein, and Maggie Wittlin for comments on drafts, and thank Sami Helgason for research assistance. Copyright (C) 2020 by Benjamin C. Zipursky.

1. See, e.g., Bristol-Myers Squibb Co. v. Superior Ct. of Ca., 137 S. Ct. 1773 (2017); Goodyear Dunlop Tires Operations, S.A. v. Brown, 564 U.S. 915 (2011).

2. Goodyear, 564 U.S. at 919.

3. Daimler AG v. Bauman, 571 U.S. 117, 137, 139 n.19 (2014).

4. Compare id. at 157-59 (Sotomayor, J., concurring), with id. at 137 (majority explaining "that only a limited set of affiliations with a forum will render a defendant amenable to all-purpose jurisdiction there," and noting that simple jurisdictional rules promote predictability); see also Bristol-Myers Squibb Co., 137 S. Ct. at 1788-89 (Sotomayor, J., dissenting). 
Decisions on specific personal jurisdiction have seemed equally striking to many court-watchers, ${ }^{5}$ and they convey a similar distrust of forum shopping. But while some of the Court's negative messages come through clearly, its overall perspective on specific personal jurisdiction remains hazy. The Justices know what they don't like, ${ }^{6}$ but they have made less progress in specifying what they do like.

With one exception. Beginning with Justice Ginsburg's 2011 opinion in Goodyear Dunlop Tires Operations v. Brown, ${ }^{7}$ and echoed in Justice Thomas's 2014 opinion in Walden v. Fiore ${ }^{8}$ and Justice Alito's 2017 opinion in Bristol-Myers Squibb v. Superior Court, ${ }^{9}$ the Court has suggested that what is distinctive about specific jurisdiction is that it is "case-linked." 10 Thus, it seems that if one could offer an adequate account of the nature of the linkage in case-linked jurisdiction, one might see a way forward. This is what has been missing, ${ }^{11}$ and it is what this article provides.

We are not the first to identify the question and to address it head on. Indeed, one of America's repeat-player litigants-Ford Motor Company-has, in litigation currently before the U.S. Supreme Court, offered the Justices a seemingly sharp-edged answer to the question

5. See, e.g., Scott Dodson, Personal Jurisdiction and Aggregation, 113 Nw. U. L. REV. 1 (2018) (following Bristol-Myers Squibb); Adam N. Steinman, Access to Justice, Rationality, and Personal Jurisdiction, 71 VAND. L. REV. 1401 (2018) (same); Robin J. Effron, Letting the Perfect Become the Enemy of the Good: The Relatedness Problem in Personal Jurisdiction, 16 LEWIS \& CLARK L. REv. 867 (2012) (following J. McIntyre Mach., Ltd. v. Nicastro, 564 U.S. 873 (2011)).

6. For example, they do not like specific jurisdiction premised solely on the plaintiff's contact with the forum state. See Walden v. Fiore, 571 U.S. 277, 284 (2014). Nor do they like a sliding scale approach that merges general jurisdiction with specific jurisdiction. See Bristol-Myers Squibb, 137 S. Ct. at 1781.

7. 564 U.S. at 919 ("Opinions in the wake of the pathmarking International Shoe decision have differentiated between general or all-purpose jurisdiction, and specific or case-linked jurisdiction.").

8. 571 U.S. at 283 n.6 (''Specific' or 'case-linked' jurisdiction 'depends on an affiliatio[n] between the forum and the underlying controversy' (i.e., an 'activity or an occurrence that takes place in the forum State and is therefore subject to the State's regulation').... This is in contrast to 'general' or 'all purpose' jurisdiction, which permits a court to assert jurisdiction over a defendant based on a forum connection unrelated to the underlying suit (e.g., domicile).").

9. 137 S. Ct. at 1780 ("Since our seminal decision in International Shoe, our decisions have recognized two types of personal jurisdiction: 'general' (sometimes called 'all-purpose') jurisdiction and 'specific' (sometimes called 'case-linked') jurisdiction.”).

10. See id.

11. See Lea Brilmayer, A General Look at Specific Jurisdiction, 42 YALE J. INT'L L. ONLINE 1, 5 (2017) ("There is little in the way of clear standards for what makes a contact with the forum 'related to' the litigation or qualifies a dispute as 'arising out of' the defendant's contacts with the forum."). 
of what "case-linked jurisdiction" requires. ${ }^{12}$ In its briefs in Ford Motor Co. v. Montana Eighth Judicial District Court, ${ }^{13}$ and Bandemer v. Ford Motor Co., ${ }^{14}$ Ford has argued that specific jurisdiction requires that a defendant's minimum contacts with the state function as a "proximate cause" of the incident giving rise to the litigation. ${ }^{15}$ Because the Respondents in both of these cases allege injuries by Ford cars that were first sold outside of the forum state, Ford argues that, despite its ample contacts with each state, both suits fail the proximate cause test, such that personal jurisdiction is lacking. ${ }^{16}$ Hence, they are asking the Court to reverse the high courts of Montana and Minnesota, each of which held that its courts could exercise specific personal jurisdiction over Ford. ${ }^{17}$ The Solicitor General and other amici have, in parallel fashion, suggested that the defendants' contacts must have been a but-for cause of the incident spawning the litigation, and that Ford wins on this alternative causation-based rendering of case-linkage. ${ }^{18}$

The Ford cases have an intuitively correct answer, however, and it is neither Ford's nor the Solicitor General's. A Minnesotan suing Ford on a claim that he was injured when a Ford vehicle's airbags malfunctioned in Minnesota should not be shut out of the Minnesota courts on grounds of personal jurisdiction, given that Ford advertises, markets, and sells many vehicles in Minnesota. Nor should the family of a Montana decedent suing Ford on a claim that she died in the rollover of a Ford vehicle in Montana be shut out of the Montana courts on grounds of personal jurisdiction, given that Ford advertises, markets, and sells many vehicles in Montana. Properly interpreted, Supreme Court precedents elaborating the content of due process restrictions on personal jurisdiction allow the Minnesota and Montana courts to hear these products liability suits. Indeed, when the jurisdictional question is stated plainly, the answer seems so obvious that it is hard to fathom any common-sense argument to the contrary.

12. Brief for Petitioner, Ford Motor Co. v. Montana Eighth Judicial Dist. Ct., 140 S. Ct. 917 (Nos. 19-368, 19-369) (Jan. 17, 2020), 2020 WL 1154744.

13. 443 P.3d 407 (Mont. 2019), cert. granted, No. 19-368, 140 S. Ct. 917 (Jan. 17, 2020).

14. 931 N.W.2d 744 (Minn. 2019), cert. granted, No. 19-369, 140 S. Ct. 916 (Jan. 17, 2020).

15. Brief for Petitioner, supra note 12, at 44.

16. Id. at $45-48$.

17. Id. at 2.

18. See, e.g., Brief for United States as Amicus Curiae Supporting Petitioner at 2632, Ford Motor Co. v. Montana Eighth Judicial Dist. Ct., 140 S. Ct. 917 (Nos. 19-368, 19369) (Jan. 17, 2020), 2020 WL 1478612. 
This is one of those situations where the intuitively correct answer is the right answer. The account we put forward explains why, under current doctrine, the courts of Minnesota and Montana have personal jurisdiction over Ford in the cases before the Supreme Court. By contrast, Ford's causation-based account, though superficially attractive, rests on a basic misunderstanding of case-linkage. If the Court were to adopt Ford's approach, it would unduly hinder state sovereignty, overextend due process constraints, and undermine courts' ability to achieve a sensible allocation of adjudicatory authority.

The principal goals of this article are constructive and interpretive, not critical or prescriptive. We aim to derive a sound theory of case-linkage from the Court's precedents and its reasoning about two pillars of personal jurisdiction: state sovereignty and due process. Part I begins the analysis by reviewing the Court's personal jurisdiction decisions from International Shoe v. Washington ${ }^{19}$ to the present with the goal of understanding the linkage concept as it has played out in the cases. Part II describes the Ford cases now at the Court.

Part III provides our theoretical explanation of the core principles of case-linked jurisdiction. There we show that two related but distinct concepts are embedded in the idea of linkage-a concept of the scope of the defendant's submission to state authority, and a concept of the scope of the forum state's interest. It is the latter concept, pertaining to the forum state's interest, that plays a critical role in its most recent case-linked jurisdiction decision, Bristol-Myers Squibb Co. v. Superior Court. ${ }^{20}$ Without describing it as such, Bristol-Myers Squibb relied upon what we refer to as the "anti-busybody principle"-the principle that a state's courts ought not meddle in affairs in which they lack sufficient interest. ${ }^{21}$ By explaining case-linkage both in terms of the scope of a defendant's submission to state power and in terms of the scope of a state's interest, we offer a way to bring together the due process and sovereignty concerns that underlie the law of personal jurisdiction. Part IV compares our framework to the alternatives, showing that causation-based approaches fail to capture the relevance of case-linkage in jurisdictional analysis.

19. 326 U.S. 310 (1945).

20. 137 S. Ct. 1773 (2017).

21. Id. at 1780. In Bristol-Myers Squibb, the Court relied on the case-linkage element to hold that the California court lacked personal jurisdiction over the defendant for the claims of non-California plaintiffs (even though it could assert personal jurisdiction over the defendant for the claims of California plaintiffs), but the case did not require the Court to spell out the meaning of the case-linkage element, and the Court did not do so. 


\section{HISTORY OF THE CASE-LINKAGE ELEMENT IN SPECIFIC PERSONAL JURISDICTION}

A careful review of modern personal jurisdiction decisions reveals that, although not always emphasized or identified as such, the case-linkage element has been a fixture of those decisions ever since the Court began distinguishing between what is today called "general" and "specific" jurisdiction. The latter distinction traces back to the foundational decision of International Shoe v. Washington. ${ }^{22}$ In that case, the Supreme Court reasoned that, when corporate presence within a state is not "so substantial and of such a nature as to justify suit against it on causes of action arising from dealings entirely distinct from those activities" 23 (what is now called "general jurisdiction"), the state's courts might nonetheless assert personal jurisdiction over the defendant based on less pervasive contacts. ${ }^{24}$ If so, however, such jurisdiction exists only for claims that "arise out of or are connected with" 25 the defendant's contacts with the forum state (what is now called "specific jurisdiction"). The Court explained the latter idea in terms of reciprocity:

$[\mathrm{T}] \mathrm{o}$ the extent that a corporation exercises the privilege of conducting activities within a state, it enjoys the benefits and protection of the laws of that state. The exercise of that privilege may give rise to obligations; and, so far as those obligations arise out of or are connected with the activities within the state, a procedure which requires the corporation to respond to a suit brought to enforce them can, in most instances, hardly be said to be undue. ${ }^{26}$

In 1966, Professors von Mehren \& Trautman coined the terms "general jurisdiction" and "specific jurisdiction."27 Following International Shoe, they described specific jurisdiction as "the assertion of power to adjudicate ... matters arising out of — or intimately related to - the affiliating circumstances on which the jurisdictional claim is based." 28

The Court recently restated the distinction between two types of personal jurisdiction this way in Bristol-Myers Squibb v. Superior Court, offering its strongest statement yet of the case-linkage component of specific jurisdiction:

22. 326 U.S. 310 (1945).

23. Id. at 318.

24. Id. at 319.

25. Id.

26. Id. (emphasis added).

27. Arthur T. von Mehren \& Donald T. Trautman, Jurisdiction to Adjudicate: A Suggested Analysis, 79 HARV. L. REv. 1121, 1136 (1966).

28. Id. at $1144-45$. 
Since our seminal decision in International Shoe, our decisions have recognized two types of personal jurisdiction: "general" (sometimes called "allpurpose") jurisdiction and "specific" (sometimes called "case-linked") jurisdiction.... A court with general jurisdiction may hear any claim against that defendant, even if all the incidents underlying the claim occurred in a different State.... Specific jurisdiction is very different. In order for a state court to exercise specific jurisdiction, "the suit" must "aris[e] out of or relat[e] to the defendant's contacts with the forum." In other words, there must be "an affiliation between the forum and the underlying controversy, principally, [an] activity or an occurrence that takes place in the forum State and is therefore subject to the State's regulation." For this reason, "specific jurisdiction is confined to adjudication of issues deriving from, or connected with, the very controversy that establishes jurisdiction." 29

So defined, specific personal jurisdiction encompasses two elements: (1) a contact element (often stated in terms of "minimum contacts" or "purposeful availment"), and (2) a case-linkage element (sometimes stated in terms of "arising out of or related to"). ${ }^{30}$ The question of what sort of contacts suffice under the minimum contacts test has been considered by the Court in a long and now-familiar sequence of decisions. The question of what sort of case-link is required, however, has received little elaboration.

International Shoe ${ }^{31}$ was an example of case-linked personal jurisdiction. In hindsight, both the contact element and the case-linkage element were easily satisfied-the suit sought recovery from the defendant of unpaid contributions to Washington's unemployment compensation fund based on the defendant's regular sale of its products in state with the help of an in-state sales force-even though the Court had not yet developed a vocabulary for breaking down the analysis in this way. ${ }^{32} \mathrm{~A}$ few years later, the Court decided Perkins v. Benguet

29. 137 S. Ct. 1773, 1779-80 (2017) (citations omitted) (emphases and parentheticals in original). In the intervening years, the Court had begun using the terms specific and general jurisdiction. See Helicopteros Nacionales de Colombia, S.A. v. Hall, 466 U.S. 408, 414 nn.8-9 (1984) (citing von Mehren \& Trautman, supra note 27).

30. For purposes of this discussion, we leave aside a third element of case-linked jurisdiction, often described as the "reasonableness" or "fairness" requirement, which the Court has suggested can function as an independent basis for a court to reject jurisdiction even if the contact element and case-linkage element are satisfied. See Asahi Metal Indus. Co. v. Superior Ct. of Ca., 480 U.S. 102, 113 (1987) (rejecting personal jurisdiction on the basis of unreasonableness); Burger King Corp. v. Rudzewicz, 471 U.S. 462, 477-78 (1985) (describing the reasonableness analysis but not deciding the case on this basis). See also Richard D. Freer, Personal Jurisdiction: The Walls Blocking an Appeal to Rationality, 72 VAND. L. REV. EN BANC 99, 116 (2019) ("Plaintiffs may appeal to [the fairness or reasonableness factors] only after scaling the wall imposed by the 'contact' requirement. Those who do must scale the emerging wall imposed by the 'relatedness' requirement.").

31. 326 U.S. 310 (1945).

32. Id. at 320 (concluding that defendant's "systematic and continuous" contacts 
Consolidated Mining Co. ${ }^{33}$ The plaintiff sued in Ohio on a claim that she was owed money as a stockholder of the Benguet Consolidated Mining Company, based in the Philippines. ${ }^{34}$ Although neither the term "allpurpose jurisdiction" nor "general jurisdiction" was yet in use, the Court emphasized that " $[t]$ he cause of action sued upon did not arise in Ohio and does not relate to the corporation's activities there." 35 The Court thus demanded a higher level of contact, which it found in the president's establishment in Ohio of the company's wartime headquarters. ${ }^{36}$

In McGee v. International Life Insurance Co., ${ }^{37}$ the Court held that even a single contact may suffice for personal jurisdiction if it bears the right relation to the suit in question. ${ }^{38} \mathrm{~A}$ Texas-based insurance company, having assumed the insurance obligations of an Arizona company, mailed a life insurance contract to a policyholder in California. ${ }^{39}$ It was the company's only contact with California. ${ }^{40}$ The policyholder's beneficiary sued the company in California for breach of contract when the company refused to pay on a claim after the policyholder died. ${ }^{41}$ Holding that California constitutionally could exercise jurisdiction over the Texas defendant to adjudicate this claim, the Supreme Court emphasized the state's interest in providing redress, particularly to its residents:

It cannot be denied that California has a manifest interest in providing effective means of redress for its residents when their insurers refuse to pay claims. These residents would be at a severe disadvantage if they were forced to follow the insurance company to a distant State in order to hold it legally accountable. 42

with the state, which resulted in a "large volume of interstate business," provided the basis for jurisdiction over a suit seeking to enforce a legal obligation that "arose out of those very activities.").

33. 342 U.S. 437 (1952).

34. Id. at $438-39$.

35. Id. at 438; see also id. at 440 (framing the issue as whether Ohio courts could proceed in personam "to enforce a cause of action not arising in Ohio and not related to the business or activities of the corporation in that State"); id. at 446 ("The instant case takes us one step further to a proceeding in personam to enforce a cause of action not arising out of the corporation's activities in the state of the forum.").

36. Id. at 447-49.

37. 355 U.S. 220 (1957).

38. Id. at 223-24.

39. Id. at 221-22.

40. Id. at 222 .

41. Id. at 221-22.

42. Id. at 223 (emphasis added). 
In several cases where the Supreme Court has rejected a plaintiff's attempt to establish specific personal jurisdiction, the Court reached its result purely on the minimum contacts element without regard to the case-linkage element. In Hanson v. Denckla, ${ }^{43}$ the Court held that a Delaware trustee could not be haled into Florida court because the trustee had not transacted any business there and thus "[t]he cause of action in this case is not one that arises out of an act done or transaction consummated in the forum State." 44 In WorldWide Volkswagen Corp. v. Woodson, ${ }^{45}$ the Court found that a New York automobile retailer and New York area distributor lacked minimum contacts with Oklahoma, and therefore the Oklahoma courts could not exercise personal jurisdiction over these sellers even though the claims arose out of an accident in Oklahoma. ${ }^{46}$ Although Oklahoma was the most convenient forum for litigating the dispute, the Court held that the state could not exercise personal jurisdiction over either of these defendants because neither had sufficient purposeful contact with Oklahoma: "[T]he Due Process Clause 'does not contemplate that a state may make binding a judgment in personam against an individual or corporate defendant with which the state has no contacts, ties, or relations.'" 47

By contrast, in cases where the Court has upheld specific jurisdiction, it has necessarily found the case-linkage element satisfied, either explicitly or implicitly. In Calder v. Jones, ${ }^{48}$ the Court upheld personal jurisdiction in California to adjudicate a defamation claim against a Florida writer and editor who had written an article about a celebrity who resided in California. ${ }^{49}$ Because the defendants knowingly produced a story about a California celebrity using California sources, and because the reputational harm would occur above all in California, the Court found the minimum contacts test satisfied. ${ }^{50}$ Equally essential, although not the focus of its opinion, the Court deemed the case-

43. 357 U.S. 235 (1958).

44. Id. at 251 .

45. 444 U.S. $286(1980)$.

46. Id. at 299.

47. Id. at 294 (quoting International Shoe Co. v. Washington, 326 U.S. 310, 319 (1945)).

48. 465 U.S. 783 (1984).

49. Id. at $785-86,791$.

50. Id. at 788-89 ("The allegedly libelous story concerned the California activities of a California resident. It impugned the professionalism of an entertainer whose television career was centered in California. The article was drawn from California sources, and the brunt of the harm, in terms both of respondent's emotional distress and the injury to her professional reputation, was suffered in California."). 
linkage element met-the suit clearly related to the defendants' contacts with California. 51

Keeton v. Hustler Magazine 52 similarly involved a defamation claim. Unlike the suit in Calder, which Jones filed in her home state at which arguably the offending article was aimed, ${ }^{53}$ Keeton did not file suit in the courts of a state with an especially strong interest in the claim, as compared with other states. ${ }^{54}$ Keeton, a New York resident, sued Ohio-based Hustler Magazine in New Hampshire to avail herself of New Hampshire's longer limitations period. ${ }^{55}$ Even so, Hustler sold numerous magazines in the state just as it did in every other state, and the article could impose reputational harm in the state just as it could in every other state. ${ }^{56}$

In Helicopteros Nacionales de Colombia v. Hall, ${ }^{57}$ the Court returned to the question of all-purpose jurisdiction, but in the process shed light on the requirements for specific jurisdiction. ${ }^{58}$ Specifically, the Court found the link element unsatisfied and therefore focused on all-purpose jurisdiction as the only potential basis for an assertion of state judicial power over the defendant. ${ }^{99}$ As in Perkins v. Benguet Consolidated Mining Co., ${ }^{60}$ the Court viewed the claim in Helicopteros as "a cause of action not arising out of or related to the corporation's activities within the State." 61 Plaintiffs had filed wrongful death actions in Texas based on deaths that occurred in a helicopter crash in Peru. ${ }^{62}$ Although the defendant Helicol had significant contacts with Texasincluding negotiations, purchases, and training-the majority found that the plaintiffs' wrongful death claims were inadequately linked to Texas to support specific jurisdiction as a prelude to its rejection of any assertion of general jurisdiction. ${ }^{63}$

51. Id. at 788 ("Here, the plaintiff is the focus of the activities of the defendants out of which the suit arises.") (citing McGee v. Int'l Life Ins. Co., 355 U.S. 220 (1957)).

52. 465 U.S. 770 (1984).

53. Calder, 465 U.S. at $788-89$.

54. Keeton, 465 U.S. at 773-74.

55. Id. at $772-73$.

56. Id. at $776-77$.

57. 466 U.S. 408 (1984).

58. Id. at $413-15$.

59. Id. at 415 .

60. 342 U.S. 437,438 (1952).

61. 466. U.S. at 409.

62. Id. at $409-10$.

63. Id. at 415 ('All parties to the present case concede that respondents' claims against Helicol did not 'arise out of,' and are not related to, Helicol's activities within Texas."). Although Justice Brennan, in dissent, urged that Helicol's contacts with Texas 
In Burger King Corp. v. Rudzewicz, ${ }^{64}$ the Court upheld specific personal jurisdiction in Florida over franchisees located in Michigan for Burger King's claim that they breached the franchise agreement. ${ }^{65}$ Burger King was headquartered in Florida and, among other things, its franchise agreement contained a Florida choice-of-law clause. ${ }^{66}$ The defendants argued that the Florida court lacked personal jurisdiction over them because the claim did not arise in Florida. ${ }^{67}$ The Court rejected this argument:

A State generally has a "manifest interest" in providing its residents with a convenient forum for redressing injuries inflicted by out-of-state actors. Moreover, where individuals "purposefully derive benefit" from their interstate activities, it may well be unfair to allow them to escape having to account in other States for consequences that arise proximately from such activities; the Due Process Clause may not readily be wielded as a territorial shield to avoid interstate obligations that have been voluntarily assumed. ${ }^{68}$

After its flurry of decisions on specific personal jurisdiction in the $1980 \mathrm{~s}^{69}$ and then a lull, ${ }^{70}$ the Supreme Court reentered the arena with gusto in 2011. Two decisions-J. McIntyre Machinery, Ltd. v. Nicastro ${ }^{71}$ and Goodyear Dunlop Tires Operations v. Brown ${ }^{72}$-signaled that there would be no dramatic expansion of personal jurisdiction, notwithstanding changes in communications, transportation, and global interchange that one might have thought would warrant such an expansion. Indeed, Nicastro's splintered opinions called into question the viability of the stream-of-commerce theory to satisfy the minimum contacts test, ${ }^{73}$ and Goodyear introduced the restrictive home-state

were related to the plaintiffs' claims, see id. at 420 (Brennan, J., dissenting), the majority declined to reach this question because the parties had not raised it. Id. at 415 n.10.

64. 471 U.S. 462 (1985).

65. Id. at $463-64,487$.

66. Id. at $464-66$.

67. See id. at 469 .

68. Id. at 473-74 (citations omitted).

69. See generally Asahi Metal Indus. Co. v. Superior Ct. of Ca., 480 U.S. 102 (1987); Burger King Corp. v. Rudzewicz, 471 U.S. 462 (1985); Helicopteros Nacionales de Colombia, S.A. v. Hall, 466 U.S. 408 (1984); Calder v. Jones, 465 U.S. 783 (1984); Keeton v. Hustler Mag., Inc., 465 U.S. 770 (1984); World-Wide Volkswagen Corp. v. Woodson, 444 U.S. 286 (1980).

70. In the interim, the Court decided Burnham v. Superior Court of California, 495 U.S. 604 (1990), which upheld personal jurisdiction over an individual based on instate service of process, and Carnival Cruise Lines, Inc. v. Shute, 499 U.S. 585 (1991), which enforced a forum-selection clause.

71. 564 U.S. 873 (2011).

72. 564 U.S. 915 (2011).

73. 564 U.S. at 881-83 (holding that the "defendant's transmission of goods permits the exercise of jurisdiction only where the defendant can be said to have targeted the forum ... it is not enough that the defendant might have predicted that its goods 
test for all-purpose jurisdiction over corporations. ${ }^{74}$ These decisions can be seen as part of a broad retrenchment in civil procedure occurring around the same time: ${ }^{75}$ one that included restrictive holdings and rules on pleadings, ${ }^{76}$ discovery, ${ }^{77}$ class certification, ${ }^{78}$ and litigation-avoidance through arbitration clauses. ${ }^{79}$ But the post- 2010 cases can also be seen as a continuation of the Court's personal jurisdiction jurisprudence, keeping fundamental principles intact from earlier cases.

Nicastro and Goodyear-as well as the Supreme Court personal jurisdiction cases that have followed them-sharpened the pair of distinctions central to jurisdictional due process analysis, namely, the distinction between all-purpose and specific jurisdiction, and the distinction, within specific jurisdiction, between the minimum contacts element and the case-linkage element. In Goodyear and then Daimler $A G$ v. Bauman, 80 the Court doubled down on the distinction between all-purpose and specific jurisdiction, holding that all-purpose jurisdiction could be used only in a defendant's home state. ${ }^{81}$ In Nicastro and then Walden v. Fiore, ${ }^{82}$ the Court reaffirmed that the contact element can be met only by a showing that the defendant acted purposefully toward the forum state. ${ }^{83}$ And finally, in Bristol-Myers Squibb Co. v. Superior Court, ${ }^{84}$ the Court affirmed the importance of the case-linkage element, holding that even if a defendant has purposefully established

will reach the forum State.").

74. 564 U.S. at $919,924$.

75. See generally STEPHEN B. BURBANK \& SEAN FARHANG, RighTS AND RETRENCHMENT: The Counterrevolution AGainst Federal Litigation (2017).

76. See generally Ashcroft v. Iqbal, 556 U.S. 662 (2009); Bell Atl. Corp. v. Twombly, 550 U.S. 544 (2007).

77. Fed. R. Civ. P. 26 (amended 2016) (highlighting proportionality as a constraint on the scope of discovery).

78. See generally Comcast Corp. v. Behrend, 569 U.S. 27 (2013); Wal-Mart Stores, Inc. v. Dukes, 564 U.S. 338 (2011).

79. See generally Epic Sys. Corp. v. Lewis, 138 S. Ct. 1612 (2018); Am. Express Co. v. Italian Colors Rest., 570 U.S. 228 (2013); AT\&T Mobility LLC v. Concepcion, 563 U.S. 333 (2011); Pamela Bookman, The Arbitration-Litigation Paradox, 72 VAND. L. REV. 1119 (2019).

80. 571 U.S. 117 (2014). (2011).

81. Id. at 127; Goodyear Dunlop Tires Operations v. Brown, 564 U.S. 915, 919

82. 571 U.S. 277 (2014).

83. Id. at 285; J. McIntyre Machinery, Ltd. v. Nicastro, 564 U.S. 873, 880 (2011).

84. 137 S. Ct. 1773 (2017). 
contacts with the forum state, specific jurisdiction is unavailable for claims that are insufficiently linked to those contacts. ${ }^{85}$

Despite the splintered Court in Nicastro, ${ }^{86}$ none of the Justices expressed any doubt about the importance of the link between the events underlying plaintiff Robert Nicastro's claim and the forum state of New Jersey. Nicastro suffered a serious injury at his place of employment in New Jersey; four of his fingers were severed on a metal-shearing machine. ${ }^{87}$ The machine was manufactured in England by J. McIntyre Machinery, Ltd. ("McIntyre"), an English company. ${ }^{88}$ But the manufacturer had not sold the machine directly to Nicastro's employer in New Jersey. ${ }^{89}$ Rather, the manufacturer sold the machine to its distributer in Ohio, who in turn sold it to the employer. ${ }^{90}$

Justice Kennedy's plurality opinion recited the facts that McIntyre did not market or sell any products directly to New Jersey and that no more than four of its machines-perhaps only the one machine at issue in this case-ended up in the state. ${ }^{91}$ With extensive citations to Hanson and World-Wide Volkswagen, the opinion then concluded that minimum contacts were absent:

Due process protects petitioner's right to be subject only to lawful authority. At no time did petitioner engage in any activities in New Jersey that reveal an intent to invoke or benefit from the protection of its laws. New Jersey is without power to adjudge the rights and liabilities of J. McIntyre, and its exercise of jurisdiction would violate due process. ${ }^{92}$

At a higher level of generality, the plurality framed the question of personal jurisdiction as a matter of whether the defendant, by its conduct, had submitted to the state's authority:

A person may submit to a State's authority in a number of ways. There is, of course, explicit consent... There is also a more limited form of submission to a State's authority for disputes that "arise out of or are connected with the activities within the state." Where a defendant "purposefully avails itself of the privilege of conducting activities within the forum State, thus invoking the benefits and protections of its laws," it submits to the judicial power of an otherwise foreign sovereign to the extent that power is exercised in connection with the defendant's activities touching on the State. In other words, submission through contact with and activity directed at a sovereign may justify

85. Id. at 1782 .

86. 564 U.S. 873 (2011).

87. Id. at 894-95 (Ginsburg, J., dissenting).

88. Id. at 878.

89. Id.

90. Id.

91. Id.

92. Id. at 887. 
specific jurisdiction "in a suit arising out of or related to the defendant's contacts with the forum." 93

Justice Breyer's concurrence, joined by Justice Alito, similarly concluded that the contact element was unmet. ${ }^{94}$ Declining to look beyond the facts in the record, Justice Breyer noted that "Mr. Nicastro, who here bears the burden of proving jurisdiction, has shown no specific effort by the British Manufacturer to sell in New Jersey." 95 Arguably, the Breyer concurrence-as the narrowest reasoning that supports the conclusion of no jurisdiction-states the rule of the Nicastro case. ${ }^{96}$ Justice Breyer explicitly declined to make any "broad pronouncements that refashion basic jurisdictional rules." ${ }^{97}$ If so, Nicastro's holding can be stated this way: A manufacturer is not subject to personal jurisdiction in a state where its product causes injury if the manufacturer has never sold anything directly into the state, and if only one item has made its way indirectly from the manufacturer into the state.

The plurality and concurrence did not speak to the case-linkage element because they found the contact element unsatisfied. ${ }^{98}$ By contrast, Justice Ginsburg's dissent, having found sufficiently purposeful contact in the manufacturer's targeting of the entire United States, addressed linkage in memorable language: "On what sensible view of the allocation of adjudicatory authority could the place of Nicastro's injury within the United States be deemed off limits for his products liability claim against a foreign manufacturer who targeted the United States (including all the States that constitute the Nation) as the territory it sought to develop?"99

The same year as Nicastro, the Court decided Goodyear Dunlop Tires Operations v. Brown. ${ }^{100}$ The Court's analysis in Goodyear focused on all-purpose jurisdiction and introduced the home-state test for all-

93. Id. at 880-81 (citations omitted); see also id. at 884 ("The question is whether a defendant has followed a course of conduct directed at the society or economy existing within the jurisdiction of a given sovereign, so that the sovereign has the power to subject the defendant to judgment concerning that conduct.").

94. Id. at 888 (Breyer, J., concurring).

95. Id. at 889.

96. Cf. Marks v. United States, 430 U.S. 188, 193 (1977) ("When a fragmented Court decides a case and no single rationale explaining the result enjoys the assent of five Justices, 'the holding of the Court may be viewed as that position taken by those Members who concurred in the judgments on the narrowest grounds...'”) (quoting Gregg v. Georgia, 428 U.S. 153, 169 n.15 (1976)).

97. Nicastro, 564 U.S. at 890 (Breyer, J., concurring).

98. Id. at 887-88 (Kennedy J.) (Breyer, J., concurring).

99. Id. at 898 (Ginsburg, J., dissenting).

100. 564 U.S. 915 (2011). 
purpose jurisdiction over corporations. 101 On the way to its holding about general jurisdiction, however, the Court rejected the application of specific jurisdiction. ${ }^{102}$ The case involved a bus rollover accident in France in which two children from North Carolina were killed.103 The decedents' parents filed a products liability suit in North Carolina, including as defendants three foreign subsidiaries of the Goodyear Tire and Rubber Company that operated in Turkey, France, and Luxembourg. ${ }^{104}$ Although some tires made by these companies had reached North Carolina in the stream of commerce, ${ }^{105}$ it was uncontested that the type of tire involved in the accident was never distributed in North Carolina, and the lawsuit had nothing to do with tires that had reached North Carolina. "Because the episode-in-suit, the bus accident, occurred in France, and the tire alleged to have caused the accident was manufactured and sold abroad, North Carolina courts lacked specific jurisdiction to adjudicate the controversy."106

In Daimler AG v. Bauman, ${ }^{107}$ the Supreme Court returned to the issue of all-purpose jurisdiction, solidifying Goodyear's home-state test. As in Goodyear, the Court easily set aside the plaintiff's specific jurisdiction argument on its way to addressing the question of all-purpose jurisdiction. ${ }^{108}$ Twenty-two Argentinian plaintiffs had filed suit in California ${ }^{109}$ against the giant German automobile manufacturer, Daimler-Chrysler AG ("Daimler"), claiming that Daimler's subsidiary, Mercedes-Benz Argentina, had collaborated in human rights abuses during Argentina's "dirty war" of 1976-83.110 It appeared that Daimler had significant contacts with California, particularly through its

\footnotetext{
101. Id. at 919,924 .

102. Id. at 919.

103. Id. at 920 .

104. Id.

105. Id.

106. Id. at 919.

107. 571 U.S. 117 (2014).

108. Id. at 133 ("Plaintiffs have never attempted to fit this case into the specific jurisdiction category.") (emphasis in original).

109. Id. at 120-21. Daimler was filed in the U.S. District Court for the Northern District of California. Id. Similarly, Burger King Corp. v. Rudzewicz and Walden v. Fiore were in federal court rather than state court. 571 U.S. 277, 281 (2014); 471 U.S. 462, 464 (1985). The fact that these cases were in federal court rather than state court did not significantly alter the personal jurisdiction analysis because Federal Rule of Civil Procedure $4(\mathrm{k})$ generally defines the territorial limits of effective service of process in terms of whether a state court in the same state would have personal jurisdiction. See, e.g., Daimler, 571 U.S. at 125 ("Federal courts ordinarily follow state law in determining the bounds of their jurisdiction over persons.") (citing Fed. R. Civ. P. 4(k)(1)(A)).

110. Daimler, 571 U.S. at 121.
} 
subsidiary, Mercedes-Benz USA, which sold many vehicles in the state.111 What was missing, however, was any link between these plaintiffs' claims and California: "The question presented is whether the Due Process Clause of the Fourteenth Amendment precludes the District Court from exercising jurisdiction over Daimler in this case, given the absence of any California connection to the atrocities, perpetrators, or victims described in the complaint."112 The Court concluded that California lacked all-purpose jurisdiction over Daimler because it was not the company's home state.113 In doing so, it emphasized that a finding of personal jurisdiction on the facts of the case would allow California to meddle in distant affairs over which the state has no legitimate interest: "If Daimler's California activities sufficed to allow adjudication of this Argentina-rooted case in California, the same global reach would presumably be available in every other State in which MBUSA's sales are sizable."114

Next, in Walden v. Fiore, ${ }^{115}$ the Supreme Court returned to the contact element of specific jurisdiction, on which it had rejected jurisdiction in Hanson, World-Wide Volkswagen, and Nicastro. The plaintiffs brought suit in Nevada against a Georgia police officer, asserting claims based on the officer's seizure of their cash at a Georgia airport. ${ }^{116}$ Although the plaintiffs resided in Nevada and claimed that the seizure caused them harm when they lacked access to funds in their home state, the Court found that the defendant lacked sufficiently purposeful contact with Nevada to satisfy the minimum contacts test, emphasizing that "it is the defendant's conduct that must form the necessary connection with the forum state."117 "In short, when viewed through the proper lens-whether the defendant's actions connect him to the forum-petitioner formed no jurisdictionally relevant contacts with Nevada."118

Finally, we arrive at the only case to date in which the Supreme Court's decision actually focused on the case-linkage element. In Bristol-Myers Squibb Co. v. Superior Court, 119 the Court held that California

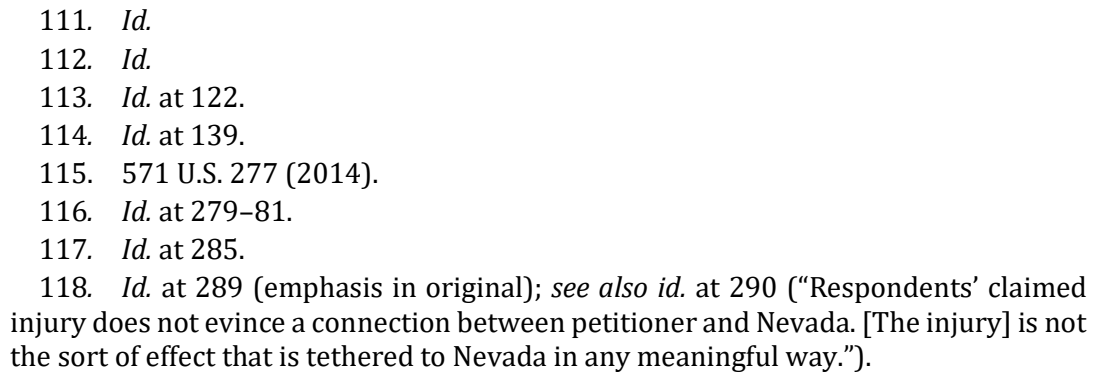

118. Id. at 289 (emphasis in original); see also id. at 290 ("Respondents' claimed injury does not evince a connection between petitioner and Nevada. [The injury] is not the sort of effect that is tethered to Nevada in any meaningful way.").

119. 137 S. Ct. 1773 (2017). 
lacked personal jurisdiction over Bristol-Myers Squibb Co. (BMS) for pharmaceutical products liability claims of non-Californians, even as California had jurisdiction over the company for the claims of Californians. ${ }^{120}$ All of the claims concerned the company's Plavix medication, which the company marketed widely throughout the United States. ${ }^{121}$ There was no doubt that BMS had substantial purposeful contacts with California. The company operated research and laboratory facilities in California, employed hundreds of sales representatives in the state, and had sold well over 100 million Plavix pills in California. ${ }^{122}$ What was missing was an adequate link between the company's contacts with California and the claims of the non-California plaintiffs:

The State Supreme Court found that specific jurisdiction was present without identifying any adequate link between the State and the nonresidents' claims. As noted, the nonresidents were not prescribed Plavix in California, did not purchase Plavix in California, did not ingest Plavix in California, and were not injured by Plavix in California. ${ }^{123}$

California lacked all-purpose jurisdiction over BMS because California was not the company's home state (BMS is incorporated in Delaware and headquartered in New York). ${ }^{124}$ It lacked specific jurisdiction over BMS for the claims of the non-Californians because, despite the company's contacts with California, the majority saw the non-California plaintiffs' claims as having no connection to California other than the fact that they had filed their lawsuit there. ${ }^{125}$ As Justice Alito explained for the majority, the due process standard for personal jurisdiction is not merely about convenience, "but it also encompasses the more abstract matter of submitting to the coercive power of a State that may have little legitimate interest in the claims in question." 126

Looking back at the modern line of Supreme Court personal jurisdiction cases, ${ }^{127}$ the structure of the analysis is clear. As a matter of federal constitutional law, in personam jurisdiction requires-in the

120. Id. at $1782-83$.

121. Id. at 1778.

122. Id.

123. Id. at 1781; see also id. at 1778 ("The nonresident plaintiffs did not allege that they obtained Plavix through California physicians or from any other California source; nor did they claim that they were injured by Plavix or were treated for their injuries in California.").

124. Id. at 1777-78.

125. Id. at 1781 .

126. Id. at 1780 .

127. Here, we focus on the central lines of personal jurisdiction analysis, and we leave aside any cases based on consent, individual in-state service of process, or in rem power over in-state property. 
absence of consent, or the service of process on an individual while physically present in the forum state-conduct by which a defendant submits to a state's adjudicatory authority. Such submission may be either all-purpose or specific. All-purpose jurisdiction over an individual is limited to the state of domicile, and all-purpose jurisdiction over a corporation is limited to its "home." Absent all-purpose jurisdiction, a state's courts can only entertain claims in a manner consistent with the requirements of specific jurisdiction. Specific jurisdiction in turn requires that two elements be satisfied-(1) the minimum contacts element and (2) the case-linkage element. What counts as a sufficient contact has been exhaustively explored by the Court, although important questions remain unanswered. What counts as a sufficient linkage, by contrast, has barely been explored, although the Court has offered hints.

\section{THE FORD CASES}

The pair of Ford cases for which certiorari was granted last term must be understood against the backdrop just provided. The Montana case concerns Markkaya Gullett, a Montana resident killed when her 1996 Ford Explorer rolled over on a Montana highway. 128 The wrongful death action brought by Charles Lucero on behalf of Gullett asserts claims based on strict products liability and negligence. ${ }^{129}$ It contends, among other things, that the relevant model of Ford Explorer had a design defect rendering it prone to rollovers. ${ }^{130}$ In this respect, the Montana suit is like hundreds of claims brought against Ford for fatal accidents. However, Gullett's Ford had originally been sold by an independent Ford dealer in Washington State, not in Montana, and it had been purchased as a used car from a non-Ford dealer in Montana. ${ }^{131}$ Ford argued on this basis that specific personal jurisdiction in Montana was lacking. ${ }^{132}$ The Supreme Court of Montana unanimously

128. Ford Motor Co. v. Montana Eighth Judicial Dist. Ct., 443 P.3d 407, 411 (Mont. 2019), cert. granted, No. 19-368, 140 S. Ct. 917 (Jan. 17, 2020).

129. Id.

130. Id.

131. Id. In both the Montana and Minnesota cases, the Ford vehicles had been resold more than once and presumably had significant "wear and tear." As a matter of products liability doctrine, the age and resale history does not preclude a strict liability claim against the manufacturer, but heightens the importance of the requirement that plaintiff bear the burden of proving that the defect existed when it left Ford's hands. In circumstances like these, a trial often focuses on design defects or failure to warn, rather than manufacturing defects. Indeed, rollover and airbag litigation typically focuses on the former theories, not the latter.

132. Id. 
disagreed, stating that "a nexus exists between the product and the defendant's in-state activity" and that "the defendant could have reasonably foreseen its product being used in Montana" in light of its extensive sales and marketing of Ford vehicles in Montana. ${ }^{133}$

Bandemer v. Ford Motor Co. ${ }^{134}$ is a companion case from Minnesota. Adam Bandemer was seriously injured when, sitting in the front passenger seat of a 1994 Ford Crown Victoria, the passenger-side airbag failed to deploy during a collision that occurred in Minnesota. ${ }^{135}$ Bandemer, like the driver of the vehicle as well as its owner, was a Minnesota resident. ${ }^{136} \mathrm{He}$ asserted products liability, negligence, and breach of warranty claims against Ford. ${ }^{137}$ However, the Crown Victoria in which Bandemer was injured had originally been sold in North Dakota, not Minnesota; it had subsequently been purchased as a used car in Minnesota. ${ }^{138}$ The fact of the car's initial out-of-state sale precluded Minnesota from exercising specific jurisdiction over it, Ford again argued. ${ }^{139}$ In a 5-2 decision, the Minnesota Supreme Court also rejected this argument, concluding that "[b]ecause there is a substantial connection between the defendant Ford, the forum Minnesota, and the claims brought by Bandemer, Ford's contacts with Minnesota suffice to establish specific personal jurisdiction over the company regarding Bandemer's claims." 140

The Supreme Court granted Ford's petition for certiorari. ${ }^{141}$ This was not entirely surprising. There is confusion among courts on how to analyze specific jurisdiction. While all jurisdictions accept that specific jurisdiction depends upon a satisfactory connection-often framing the inquiry in terms of the "relationship among the defendant, the forum, and the litigation" and in terms of whether the claims "arise out of or relate to" the defendant's in-state contacts-jurisdictions have varied in exactly how they interpret this requirement. Some courts have interpreted these phrases to demand a "proximate cause" relationship between the defendant's in-state contacts and the case before

133. Id. at 416.

134. Bandemer v. Ford Motor Co., 931 N.W.2d 744 (Minn. 2019), cert. granted, No. 19-369, 140 S. Ct. 916 (Jan. 17, 2020).

135. Id. at 748 .

136. Id.

137. Id.

138. Id. at 757-58 (Anderson, J., dissenting).

139. Id. at 748 .

140. Id. at 755 .

141. Ford Motor Co. v. Montana Eighth Judicial Dist. Ct., 140 S. Ct. 917 (Jan. 17, 2020); Ford Motor Co. v. Bandemer, 140 S. Ct. 916 (Jan. 17, 2020). 
the court.142 Others have contended that "proximate cause" is the wrong test, and required instead "but for" causation. ${ }^{143}$ And other courts still reject the idea of a causation requirement. ${ }^{144}$

As noted, Ford urges a proximate cause standard. ${ }^{145}$ Numerous amici from the business community have urged the Court to side with Ford (but not all have). ${ }^{146}$ The gist of Ford's argument is stated in its summary: "Because due process requires suit-related contacts, the arise-out-of-or-relate-to requirement is met only if the defendant's forum conduct gave rise to the plaintiff's claims." ${ }^{147}$ In the substance of the brief, Ford spells out its reasoning:

A causal test locates jurisdiction in those States that have a regulatory interest in the plaintiff's claims because it grounds jurisdiction in an act the defendant itself took inside or purposefully aimed at a State that led to the plaintiff's claims. The test, for example, permits the State where a defendant manufactured the product at issue in a plaintiff's suit to exercise jurisdiction. That State has an interest in preventing the manufacture of harmful products within its borders and in not allowing companies to use the State's resources to do so. The same goes for the State where a defendant designs or sells its product. Under a causal rule, States with an interest in regulating what Ford does within their borders will have jurisdiction when a plaintiff's claims seek to do just that. ${ }^{148}$

The Respondents' Brief in Opposition opposes a causal test, arguing that the Court has never before laid down a causal requirement (let alone a proximate causal requirement) for specific personal jurisdiction, and contending:

This Court has repeatedly made clear that where (a) a company deliberately cultivates a market for a product in the forum state, and (b) that product causes an injury in the forum state, the relationship between the injury and

142. See, e.g., Beydoun v. Wataniya Rests. Holding, 768 F.3d 499, 507-08 (6th Cir. 2014); Mass. Sch. of L. at Andover v. Am. Bar Ass'n, 142 F.3d 26, 35 (1st Cir. 1998).

143. See, e.g., Mattel, Inc. v. Greiner \& Hausser GmbH, 354 F.3d 857, 864 (9th Cir. 2003); Terracom v. Valley Nat'l Bank, 49 F.3d 555, 561 (9th Cir. 1995); Prejean v. Sonatrach, Inc., 652 F.2d 1260, 1270 n.21 (5th Cir. Unit A Aug. 1981); see also Nowak v. Tak How Invs., 94 F.3d 708, 714 (1st Cir. 1996) (referring to the Ninth Circuit as "the most forceful defender of the 'but for' test.").

144. See, e.g., Shoppers Food Warehouse v. Moreno, 746 A.2d 320, 335-36 (D.C. Cir. 2000); Chew v. Dietrich, 143 F.3d 24, 29-31 (2d Cir. 1998).

145. Brief for Petitioner, supra note 12, at 44.

146. See, e.g., Brief of the Chamber of Commerce of the United States of Am., the Nat'l Ass'n of Mfrs., and the Am. Tort Reform Ass'n as Amici Curiae in Support of Petitioner, Ford Motor Co. v. Montana Eighth Judicial Dist. Ct., 140 S. Ct. 917 (Nos. 19-368, 19-369) (Jan. 17, 2020), 2020 WL 1478608. But see Brief of the Nat'l Ass'n of Home Builders as Amicus Curiae in Support of Respondents, Ford Motor Co. v. Montana Eighth Judicial Dist. Ct., 140 S. Ct. 917 (Nos. 19-368, 19-369) (Jan. 17, 2020), 2020 WL 1852280.

147. Brief for Petitioner, supra note 12, at 13 (emphasis in original).

148. Id. at 41 . 
the defendant's in-state activity is sufficient for specific jurisdiction. The principles that animate the relatedness requirement-fair warning and reciprocal obligation-strongly weigh in favor of jurisdiction in this paradigmatic scenario, regardless of where the particular widget that caused injury in the forum happened to have first been sold. ${ }^{149}$

Respondents argue that Ford's proposed test goes beyond the Court's decision in Bristol-Myers Squibb, pointing out that petitioners in that case asked the Court to adopt a causation test and it declined to do so. 150

On our view, each side has valid points, but neither side captures the jurisdictional values at stake. The Respondents are correct that the Court's precedents do not dictate a causal test; they are correct that Bristol-Myers Squibb and Nicastro-and indeed all other Court decisions declining to find specific jurisdiction-are distinguishable; and they are correct that selecting the notoriously elusive concept of "proximate cause" will not enhance clarity. On the other hand, Ford is correct that many lower courts have adopted some form of causation rule; it is correct that International Shoe and Keeton-and indeed all other Court decisions finding specific jurisdiction-are distinguishable; and it is correct that there is something of a mess in the lower courts, such that clarification would be useful. Unfortunately, none of the parties has put forward an affirmative account of the basic principles underlying case-linked jurisdiction and the framework of requirements that would give force to these principles.

\section{THE TWO PRINCIPLES EMBEDDED IN THE CASE-LINKAGE ELEMENT}

In this Part we explain that the key to making sense of-and hence properly applying - the Court's conception of personal jurisdiction is to grasp that there are two distinctions, operating at two different levels, built into the idea of specific or case-linked jurisdiction. First, specific jurisdiction involves two elements: (1) minimum contacts and (2) case-linkage. Second, the case-linkage element itself has two aspects: (a) the scope of a defendant's submission to the forum state's power and (b) the scope of the forum state's interest. These two aspects of case-linkage correspond to and articulate two principles: one involving defendant submission to a forum state and one involving scrutiny of the legitimate interests of forum states.

149. Brief of Respondents at 10, Ford Motor Co. v. Montana Eighth Judicial Dist. Ct., 140 S. Ct. 917 (No. 19-398, 19-369) (Jan. 17, 2020), 2020 WL 1531238.

150. Id. at 25-26. 
Our goal in isolating the distinct ideas contained within standard phrasings is to explain how each serves a different function in the analysis of case-linked jurisdiction and thus to enable greater clarity and consistency in judicial decision-making. However, given that we break down the requirements for specific jurisdiction into two elements, and then further break down the second element into two aspects-all of which must be satisfied before jurisdiction is presentsome readers might be tempted to conclude that we have fashioned an especially defendant-friendly test. In fact, our analysis lacks any such valence. Indeed, as we demonstrate below, it explains precisely why the Court in the Ford cases should affirm the lower courts' findings of jurisdiction.

\section{A. Relation Among Defendant, Forum, ANd Litigation}

The duality of case-linkage and the two principles underlying it generate a range of ambiguities built into the standard ways of discussing specific jurisdiction. Courts-including the Supreme Courtoften describe the inquiry in terms of "the relationship among the defendant, the forum, and the litigation." 151 This triangular phrase could imply three different two-part connections, a broader three-part connection, or both. Because of this ambiguity, the phrase ultimately does not help refine the analysis, even as it gets much right. The phrase correctly but problematically encompasses both the contact element and the case-linkage element, and it correctly but problematically encompasses both the forum-state-interest aspect and the submission-tostate-power aspect of the case-linkage element. To understand how case-linked jurisdiction works, we need to pull the phrase apart and understand the analysis step by step.

Specific jurisdiction first requires a relationship between the defendant and the forum. This is the minimum contacts requirement. Unless a defendant has "purposefully availed" itself of a forum state, the state cannot exercise specific jurisdiction over the defendant. 152 But beyond minimum contacts, specific jurisdiction requires that the litigation must be within the range of matters over which the defendant's purposeful contacts with the forum count as submission to the adjudicatory authority of the forum state and that the events giving rise to the litigation must give the forum state an adequate basis for

151. Shaffer v. Heitner, 433 U.S. 186, 204 (1977) (emphasis added); accord Walden v. Fiore, 571 U.S. 277, 284 (2014); Helicopteros Nacionales de Colombia S.A. v. Hall, 466 U.S. 408, 414 (1984); Keeton v. Hustler Mag., Inc., 465 U.S. 770, 775 (1984).

152. Hanson v. Denckla, 357 U.S. 235, 253 (1958); see also Burger King Corp. v. Rudzewicz, 471 U.S. 462, 474-75 (1985). 
asserting its adjudicatory authority. These are related ideas. Both concern case-linkage-and both can be described in terms of "the relationship among the defendant, the forum, and the litigation." However, they are distinct because one aspect looks at the question from the angle of the defendant's purposeful contacts, and the other looks at the question from the angle of the forum state's interest. 153

Because both aspects of case-linkage are in addition to the minimum contacts requirement itself, and because both pertain to features of the individual case that concern the relationship between the defendant and the forum state, these requirements often get subsumed in the single question of whether the claim "arises out of or relates to" the defendant's contacts with the forum state. As noted, a major aim of this article is to isolate the distinct ideas contained within the standard phrasings by explaining how each aspect serves a different function in the analysis of case-linked jurisdiction.

\section{B. The Anti-Busybody Principle}

Until the Court's recent revisitations of personal jurisdiction, the overwhelming focus of the Court's attention to specific personal jurisdiction concerned the degree to which a legal actor had, by purposefully availing itself of the forum state, submitted itself to that state's courts. An array of recent decisions by the Court-Goodyear, ${ }^{154}$ Daimler, ${ }^{155}$ and most importantly Bristol-Myers Squibb ${ }^{156}$ - has revealed that specific jurisdiction is not only about whether a defendant has so many contacts with a state that it cannot complain that it is being unfairly burdened by having to litigate there. It is about whether this state, among all jurisdictions, has any business adjudicating the particular claims against the defendant that the plaintiff has brought. 157 This question-sometimes referred to as the principle of "interstate

153. See Effron, supra note 5, at 872 (describing the two dimensions of the relatedness problem in terms of the relationship between the defendant and the forum, and the relationship between the lawsuit and the forum).

154. 564 U.S. 915 (2011).

155. 571 U.S. 117 (2014).

156. 137 S. Ct. 1773 (2017).

157. Our analysis addresses the jurisdictional reach of state courts as a constitutional matter; it does not address the jurisdictional reach of federal courts as a constitutional matter. Because of Federal Rule of Civil Procedure 4(k), limits on state-court jurisdictional reach currently translate into restrictions on federal-court jurisdictional reach in most cases. Nothing in our analysis, however, undermines the perfectly reasonable idea that, with appropriate statutory authorization, federal courts could offer broader jurisdictional reach to facilitate nationwide aggregation and other goals. See generally Dodson, supra note 5; A. Benjamin Spencer, Nationwide Personal Jurisdiction for our Federal Courts, 87 DENVER U. L. REv. 325 (2010). 
federalism"158_does indeed implicate defendant's due process rights, but it simultaneously concerns respect for the sovereignty of other states and other jurisdictions. ${ }^{159}$ As Justice Alito analyzed it in BristolMyers Squibb, states exceed their jurisdictional authority if they are too willing to exercise their own power in cases that are not their business-where they do not have a "legitimate interest."160

We shall refer to the "no-legitimate-interest" concern highlighted in Bristol-Myers Squibb as "the busybody problem." The point is that a state's courts ought not meddle in affairs beyond the state's legitimate domain of interest; if a court does so (without a defendant's consent), and thereby exceeds the domain of the state's sovereign power in attempting to make a binding determination of the defendant's rights and obligations, it violates a defendant's due process rights. In BristolMyers Squibb, to the extent the California court exercised jurisdiction over the out-of-state defendant for the claims of Californians allegedly harmed by the defendant's drug in California, there was no busybody problem. There was a busybody problem, however, to the extent the California court purported to exercise jurisdiction over the out-ofstate defendant for the claims of out-of-state plaintiffs arising outside of California. In holding that California lacked specific jurisdiction over BMS for the claims of the non-California plaintiffs, ${ }^{161}$ the Supreme Court was giving effect to the anti-busybody principle.

Once the anti-busybody principle is identified, it is easy to spot it at work in other cases. In Daimler, a group of Argentinian plaintiffs brought suit in the Northern District of California against Daimler, a German company, regarding injuries in Argentina allegedly caused by Daimler's Argentinian subsidiary. ${ }^{162}$ The Supreme Court held that California's courts ${ }^{163}$ lacked personal jurisdiction. ${ }^{164}$ The Court focused on the question of general jurisdiction because it was clear that

158. Bristol-Myers Squibb, 137 S. Ct. at 1780; World-Wide Volkswagen Corp. v. Woodson, 444 U.S. 286, 294 (1980).

159. See Brilmayer, supra note 11 , at $13-14$.

160. $137 \mathrm{~S}$. Ct. at 1780 ("Assessing this burden obviously requires a court to consider the practical problems resulting from litigating in the forum, but it also encompasses the more abstract matter of submitting to the coercive power of a State that may have little legitimate interest in the claims in question.").

161. Id. at 1783-84.

162. See Daimler AG v. Bauman, 571 U.S. 117, 120-21 (2014).

163. Because Federal Rule of Civil Procedure $4(\mathrm{k})$ generally frames the territorial reach of service of process for federal courts in terms of whether a state court would have jurisdiction, the Supreme Court analyzed the personal jurisdiction of the district court in terms of California's jurisdiction. See id. at 125.

164. Id. at 121-22. 
specific jurisdiction was absent in Daimler. 165 The anti-busybody principle explains exactly why the lack of case-linked jurisdiction was so clear. If a California court were to purport to adjudicate claims that arose entirely in Argentina against a German company, it would be meddling in affairs over which its state lacks sufficient interest.

Similarly, in Goodyear, the Supreme Court held that North Carolina lacked personal jurisdiction over French, Turkish, and Luxembourgian defendants for wrongful death claims involving a bus rollover accident in France. ${ }^{166}$ As in Daimler, the Court focused on the question of general jurisdiction because specific jurisdiction was clearly absent. ${ }^{167}$ And again, the lack of specific jurisdiction is explicable in terms of the busybody problem. If a North Carolina court were to purport to adjudicate claims against foreign manufacturers for claims arising out of an accident in France-only because the victims were from North Carolina-the court would be meddling in affairs beyond the domain of the state's sovereign power. The Supreme Court's message to state courts in Goodyear, Daimler, and Bristol-Myers Squibb is clear: don't be a busybody.

\section{SCOPE OF SUBMISSION}

Even if a case presents no busybody problem, however-that is, even if the forum state has an interest in the matter that places the dispute between plaintiff and defendant within the domain of the state's power-the court may nonetheless lack personal jurisdiction over the defendant. This failure of jurisdiction comes in two forms: one straightforward, the other subtle.

The straightforward version of the problem is handled through the minimum contacts element. These are cases in which the dispute centers on an occurrence within the forum state, but a particular defendant has no purposeful contacts with the state. This was the situation in World-Wide Volkswagen, where the Court held that Oklahoma lacked personal jurisdiction over the New York dealer and distributor because these defendants lacked minimum contacts with Oklahoma. ${ }^{168}$

165. See id. at 133 ("Plaintiffs have never attempted to fit this case into the specific jurisdiction category.") (emphasis in original).

166. Goodyear Dunlop Tires Operations, S.A. v. Brown, 564 U.S. 915, 918 (2011).

167. See id. at 919 ("Because the episode-in-suit, the bus accident, occurred in France, and the tire alleged to have caused the accident was manufactured and sold abroad, North Carolina courts lacked specific jurisdiction to adjudicate the controversy.").

168. See World-Wide Volkswagen Corp. v. Woodson, 444 U.S. 286, 295-96 (1979). 
Yet even if a case presents neither a minimum contacts problem (that is, the defendant purposefully availed itself of the forum state in some way) nor a busybody problem (that is, the forum state has sufficient legitimate interest in the matter), the court may nonetheless lack personal jurisdiction over a defendant if the defendant's contacts do not constitute submission to the state's authority with regard to the dispute in a particular case. For case-linked personal jurisdiction, the respects in which the defendant has purposefully availed itself of the state must not be unrelated to the claims brought by the plaintiff, because if they are, the defendant's contacts do not count as submission for that kind of suit. Thus, in World-Wide Volkswagen, if the New York dealer had had purposeful contacts with Oklahoma that were completely unrelated to the Robinson's claim, the court would still have lacked personal jurisdiction over the dealer. In this hypothetical scenario, the minimum contacts element would have been satisfied, and the anti-busybody principle would have been satisfied, but the case would not have fallen within the scope of the defendant's submission to the state's power.

While the question of scope of submission does not admit of treatment under a bright-line rule, it identifies an issue of salient constitutional significance and frames a judicially manageable inquiry about it. By focusing on whether the subject matter of the suit falls within the type of adjudication that is implicated by the defendant's purposeful contacts with the forum state, this prong trains judicial attention on the heart of the due process inquiry. If the defendant is being sued for a matter that relates to its purposeful availment of the forum state, then the defendant has fair notice of the type of suit that it might have to defend there. ${ }^{169}$

169. Although, as we discuss below, some (including Ford in the litigation now before the Court) have aimed to characterize this inquiry by reference to the negligencelaw concept of proximate cause, a more apt tort analogy for the scope-of-submission inquiry comes from the law of defamation. In determining who counts as a public figure so as to benefit from the "actual malice" rule of New York Times Co. v. Sullivan, 376 U.S. 254 (1964), the Supreme Court has contrasted "general purpose" public figuresroughly, household names-with "limited purpose" public figures-persons who are in the public eye because of their involvement in a controversy that has received public attention. Gertz v. Robert Welch, Inc., 418 U.S. 323 (1974). Ordinarily, for persons to be deemed limited purpose public figures, they must "thrust themselves to the forefront of particular public controversies in order to influence the resolution of the issues involved." Id. at 345 . The core idea is that one who chooses to become involved in a matter receiving or likely to receive public attention submits to certain kinds of scrutiny and criticism, but only if related to that matter. In fleshing out what it means for the scrutiny and criticism to be properly "related to" the controversy, courts have recognized that a broad range of facts about a person are relevant. They have therefore treated statements about a plaintiff as related to the controversy in question when 


\section{Putting IT All Together}

Our central claim is that the case-linkage element incudes both the anti-busybody principle and the scope-of-submission principle. More broadly, case-linked jurisdiction demands minimum contacts plus a relationship among the defendant, the forum, and the litigation-a case link - that satisfies both of these requirements. The antibusybody principle and the scope-of-submission principle are both rooted in due process, and both concern whether a defendant can reasonably anticipate being haled into court by the state on a matter of this kind. As to the busybody problem, defendants cannot be expected to anticipate that a state will exercise power on a matter in which it has no legitimate interest, and even if they could anticipate it, they should not be subject to it. As to the scope of submission, a defendant's purposeful availment of the state in some respect cannot be construed as an all-purpose submission to a state's power: there is a certain scope of matters one could be deemed to have submitted to, and a defendant can only be expected to anticipate being haled into court in a state for matters within that scope. When courts describe the caselinkage requirement in terms of whether the claim "arises out of or relates to" the defendant's contacts, they capture only part of the picture, and they capture it misleadingly, because the "arising out of or related to" framing confusingly blurs the scope-of-submission principle and the anti-busybody principle.

Under the scope-of-submission principle, the kind of claims a plaintiff asserts must be related to the defendants' purposeful contacts with the forum state. That is because, absent consent, the defendant's "purposeful availment" of the state constitutes the basis of the defendant's submission to state power for purposes of the due process analysis. For specific jurisdiction over a defendant, one question is whether the kinds of claims involved in the litigation are properly construed as being within the scope of that submission. Thus, the

they concern "talents, education, experience and motives [that] could have been relevant to the public's decision whether to listen to [her]," Waldbaum v. Fairchild Publications, Inc., 627 F.2d 1287, 1298 (D.C. Cir. 1980), cert. denied, 449 U.S. 898 (1980), quite apart from whether these pertain directly to the facts of the specific controversy. See generally 1 RoBERT D. SACK, SACK ON DEFAMATION: LIBEL, SLANDER AND RELATED PROBLEMS, $\S 5.3 .3$ (5th ed. 2017) (explaining the relatedness requirement for limited purpose public figure doctrine). In sum, the principle that a limited purpose public figure's invitation of public attention fairly subjects her to a higher degree of public scrutiny generates an inquiry about the connection between the scope of added public scrutiny and the character of the public attention invited. Similarly, the principle that the defendant's purposeful availment of the state demonstrates a higher degree of submission to the adjudicative authority of a state's courts generates an inquiry about the connection between the scope of that authority and the character of the purposeful availment. 
relatedness idea in the phrase "arising out of or related to" captures the thrust of the requirement that specific jurisdiction fall within the scope of a defendant's submission to the forum state's authority by virtue of the defendant's purposeful connection with the state.

But relatedness is not the whole picture. The case-linkage element requires more than merely that the plaintiff's claims be related to the defendant's contacts. Otherwise, the California court in Bristol-Myers $S q u i b b$ would have had jurisdiction over the defendant for the claims of the non-Californians, which surely were related to the defendant's nationwide marketing and sale of Plavix, including in California, as Justice Sotomayor pointed out in her dissent. 170 In addition to a showing of relatedness to satisfy the scope-of-submission principle, the case-linkage element requires satisfaction of the anti-busybody principle. It is the latter principle that explains why the California court lacked jurisdiction over BMS for the claims of the non-Californians. Case-linked jurisdiction requires that the forum state's interest in the dispute between the plaintiff and the defendant suffice to permit the forum state to exercise sovereignty. As to that question, relatedness to the contacts constituting the defendant's purposeful availments is not always sufficient. The defendant's involvement in the events generating the litigation must be such as to create the basis for the forum state to use its courts to hold the defendant accountable to the plaintiff in some manner, assuming the "submission" factor is present.

In the Ford cases pending before the Court, it is to Ford's credit that it attempts to justify its proposed rule by reference to an argument about why neither Montana nor Minnesota has an adequate basis for asserting its authority as a sovereign in the respective cases. ${ }^{171}$ Yet that argument displays basic misconceptions about products liability, federalism, and state sovereignty. Ford argues, in essence, that because the car that killed Gullett was initially sold in the state of Washington and not in Montana, the regulatory basis of jurisdictional power is in Washington, rather than in Montana. ${ }^{172}$ It offers a similar argument with regard to Bandemer: the car involved in that crash was initially sold in North Dakota, not in Minnesota, so the regulatory interest that would warrant a state's assertion of sovereignty over Bandemer's claim against Ford belongs to North Dakota, not

170. Bristol-Myers Squibb Co. v. Superior Ct. of Ca., 137 S. Ct. 1773, 1786 (Sotomayor, J., dissenting).

171. Brief for Petitioners, supra note 12 , at 26-27.

172. Id. at $45-48$. 
Minnesota. 173 Of course Ford's arguments are not phrased in the terms of our approach, but it is not difficult to see how it would apply.

Ford's invocation of Bristol-Myers Squibb against Montana and Minnesota is tantamount to an assertion that those states are being busybodies, just as California would have been if the Court had not reversed the California Supreme Court's decision regarding the non-California plaintiffs. Whether a state is being a busybody turns on which of its interests, if any, are at stake. Putting to one side, for the moment, the issues of purposeful availment and scope of submission that figured prominently in cases such as World-Wide Volkswagen (we turn to these below), the thought that Montana and Minnesota have no interest in providing redress to victims of torts that occur within their respective borders is preposterous. Indeed, the only way in which it can be rendered even superficially plausible is if one supposes that a state's interest in applying its tort law is exhausted by the ex ante, deterrent effect of such law. Of course, tort law sometimes does have a deterrent impact, and much late-twentieth-century tort scholarship (including that of the law and economics school) has added greatly to our understanding of this idea. ${ }^{174}$ But it would be absurd for the Supreme Court, in analyzing a due process problem, to treat a state's interest in providing tort law as limited to its interest in deterrence. The common law of torts in every state, no less than the common law of contract, has always been understood equally as a law of redress or accountability. To quote again the Court's own language from Burger King: "A State generally has a 'manifest interest' in providing its residents with a convenient forum for redressing injuries inflicted by outof-state actors." 175 Indeed, even in punitive damages law-the aspect of tort law that comes closest to being purely regulatory-the Court has decided there is and constitutionally must be a fundamentally individual-plaintiff, non-regulatory orientation, and that the individual accountability features of tort law are central to due process analysis. ${ }^{176}$

The foregoing is not a mere theoretical point. If, as Ford itself has maintained, the proper analysis of case-linked jurisdiction is a matter

173. Id.

174. John C.P. Goldberg, Twentieth-Century Tort Theory, 91 GE0. L. J. 513, 544-60 (2003).

175. Burger King Corp. v. Rudzewicz, 471 U.S. 462, 473 (1985).

176. Philip Morris USA v. Williams, 549 U.S. 346 (2007) (holding that the amount of punitive damages awarded to a tort plaintiff must be set by reference to the mistreatment by the defendant of the plaintiff, not by the losses the defendant's conduct may have inflicted on others). 
of "interstate federalism," it is crucial that we understand what gives each state the power to subject defendants to adjudication of civil cases, including tort cases, in its courts. ${ }^{177}$ Tort law, unlike regulatory law, draws an essential connection between the defendant's unlawful conduct and the victim's power to obtain compensation: it is equally a law of conduct-guidance and liability. So, when it comes to capturing Minnesota's or Montana's authority to administer and apply this basic and longstanding body of law, the question is not properly framed, narrowly, in terms of each state's interest in ensuring the manufacture and sale of suitably safe new cars in its territory. That is the pure ex ante regulation view. Each state has the authority-and indeed the responsibility-not only to set rules and standards for how individuals and firms must avoid causing injuries to others, but also to enable persons within its territory who are injured by violations of those rules and standards to hold the injurer accountable through its courts. Tort law-as a system for redressing wrongs and obtaining compensation for injury-has substantial status within each state's constitutional law, and our federal Due Process Clause has been understood by the Supreme Court to incorporate that status. ${ }^{178}$

Thus, while tortious conduct by an actor within a state can be one basis for a state's legitimate interest in providing a forum for redress, it is not the only basis. Another basis for the state's interest is tortious injury within a state. ${ }^{179}$ If the tortfeasor (or its agents) happen not to

177. Although the Supreme Court made it clear in Insurance Corp. of Ireland v. Compagnie des Bauxites de Guinée, 456 U.S. 694, 702 (1982), that the personal jurisdiction requirement protects an individual liberty interest, and explicitly downplayed the notion of sovereignty, concerns about sovereignty and interstate federalism have never disappeared from personal jurisdiction analysis and are built into the due process analysis, as the Court revealed emphatically in Bristol-Myers Squibb. v. Superior Court, 137 S. Ct. 1773, 1780 (2017).

178. John C.P. GoldBerg \& Benjamin C. Zipursky, ReCognizing Wrongs 30-43 (2020).

179. It is worth noting that the common law of torts does not embrace a sharp distinction between tortious acts and tortious injuries. Nor should it. As two of us (among others) have shown, the wrongs of tort law are "injury-inclusive": a tort is not committed until potentially injurious conduct is actualized in injury. See id. at 28, 92-98, 18388. This idea is no mere philosopher's indulgence. It is and always has been core to the domains of overlap between civil procedure and torts, as topics from statutes of limitation to choice-of-law to venue and personal jurisdiction reflect. Moreover, the Court's own tort decisions from defamation to products liability to punitive damages have reflected the same theme. Indeed, the particular account of the "injury-inclusiveness" of tortious wrongdoing developed by Goldberg and Zipursky grew in part out of a defense and explanation of the Court's opinion in Metro-North Commuter Railroad Co. v. Buckley, 521 U.S. 424 (1997), which rejected the idea that plaintiffs who had not yet suffered injury from asbestos exposure presented a mere "damages" problem. Id. at 444 . 
be physically present in the state when the plaintiff is tortiously injured, that itself does not undercut the legitimacy of the state's interest in adjudicating a claim against that tortfeasor. The Court's decision in McGee makes the analogous point as to contract claims: "It cannot be denied that California has a manifest interest in providing effective means of redress for its residents when their insurers refuse to pay claims." 180 In terms of the elements of specific personal jurisdiction, the minimum contacts element trains attention specifically on the actor's purposeful conduct vis-à-vis the forum state, but if the element of purposeful contact is met, then the anti-busybody aspect of the case-linkage element may be satisfied by interests that go beyond the state's interest in ex ante regulation of in-state conduct. The Court has repeatedly pronounced that the identification of torts and the provision of court-ordered compensation for them is a basic function of state law. ${ }^{181} \mathrm{~A}$ state is not being a busybody when it fulfills its responsibility to provide a forum for redress of tortious injuries occurring within the state.

We can illustrate our point by comparing Goodyear, Daimler, and Bristol-Myers Squibb, on the one hand, with World-Wide Volkswagen, Nicastro, and the Ford cases on the other, and then comparing WorldWide Volkswagen and Nicastro with the Ford cases. In Goodyear, Daimler, and Bristol-Myers Squibb, the relevant incidents and injuries occurred entirely outside of the forum state, whereas in each of WorldWide Volkswagen, Nicastro, and the Ford cases, the relevant accident

Instead, the Court rightly concluded that there was a liability problem, because the defendant who negligently exposes someone to asbestos fibers has not by that fact alone committed the tort of negligence-there must also be a resulting injury, such as bodily harm. See John C.P. Goldberg \& Benjamin C. Zipursky, Unrealized Torts, 88 VA. L. REV. $1625,1699-1701$ (2002). In a products liability case, the product's malfunction and causing of injury in the state matter to the personal jurisdiction analysis, even if those contacts might not themselves establish purposeful availment by the defendant: the sorts of contacts that satisfy the minimum contacts element (purposeful availment) are not the only contacts that matter for the case-linkage element of specific jurisdiction. In any event, a proper understanding of sovereignty, territoriality, and tort law in our federalist system requires recognition that, in an important sense, a defendant commits a tort in the state where wrongful acts ripen into actual injury. Notwithstanding these observations and their deep grounding in the common law and the Court's own decisions, the analysis in the body of the essay assumes arguendo a more reductive approach according to which tortious acts and tortious injury are separated.

180. McGee v. Int'l Life Ins. Co., 355 U.S. 220, 223 (1957).

181. See, e.g., Wos v. E.M.A., 568 U.S. 627, 639-40 (2013) ("In our federal system, there is no question that States possess the 'traditional authority to provide tort remedies to their citizens' as they see fit.") (quoting Silkwood v. Kerr-McGee Corp., 462 U.S. 238, 248 (1984)); Bates v. Dow Agrosciences LLC, 544 U.S. 431, 449 (2005) (emphasizing the longstanding availability of tort compensation through state court actions). 
and injury occurred in the forum state. For this reason, the anti-busybody principle precluded specific jurisdiction in Goodyear, Daimler, and Bristol-Myers Squibb, but not in the others. There was nothing busybody-ish about Oklahoma, New Jersey, Montana, and Minnesota asserting an interest in adjudicating the claims arising from in-state accidents in World-Wide Volkswagen, Nicastro, and the Ford cases. But the case-linkage element, with its anti-busybody principle, is only one piece of the analysis; the minimum contacts element must be satisfied as well. Thus, in World-Wide Volkswagen and Nicastro, the Court found that a tortious injury in the state was not sufficient, because minimum contacts by the defendant were absent. ${ }^{182}$ On this point, of course, the Ford cases are very different: no one disputes that Ford sold large numbers of vehicles in each state. Thus, the Ford cases resemble Daimler and Bristol-Myers Squibb in demonstrating minimum contacts, and they resemble World-Wide Volkswagen and Nicastro in not raising the busybody problem.

One might ask: If the state has a legitimate interest in providing redress to persons tortiously injured in their state, why shouldn't the analysis end there, permitting case-linked jurisdiction in cases like World-Wide Volkswagen and Nicastro? The answer is that the busybody analysis goes only to the legitimacy of the state's interest in adjudicating the claims. It does not address the other aspects of the due process analysis, which concern whether a defendant has acted purposefully toward a state in a way that counts as a submission to state authority (the minimum contacts element), and if so, whether the particular dispute falls within the scope of the defendant's submission (the scope-of-submission aspect of the case-linkage element). The presence of in-principle power based on the state's interest in providing a forum for redress of injuries does not answer whether the defendant has submitted to the jurisdiction of the state. Yet if the defendant has purposefully availed itself of the state, if the defendant has done so in ways that are directly related rather than tangential to the state's assertion of power in the case at hand, and if the state has a legitimate interest in adjudicating the dispute, then all of the requirements of case-linked jurisdiction are satisfied. By selling its vehicles in Montana and Minnesota, Ford submitted to the authority of the courts of those states to hear claims against it arising out of the use of those cars. This is why there is no scope-of-submission problem in the Ford cases. Given Ford's extensive contacts with those states, and the absence of any busybody problem, Ford was, in these cases, properly

182. J. McIntyre Mach., Ltd. v. Nicastro, 564 U.S. 873, 886-87 (2011); World-Wide Volkswagen Corp. v. Woodson, 444 U.S. 286, 299 (1980). 
subject to the jurisdiction of the Montana and Minnesota courts, respectively.

Our approach is conservative and grounded in the case law. Indeed, more than fifty years ago, Professors von Mehren and Trautman described a very similar approach as "conservative" in their famous and oft-cited Harvard Law Review article. ${ }^{183}$ Applying our analysis to the Ford cases and comparing those cases to the Supreme Court's prior decisions, one can see that each of the requirements of caselinked jurisdiction is satisfied. First, the minimum contacts element is obviously met. As both the Montana and the Minnesota courts found, Ford purposefully availed itself of their states by their extensive instate marketing, sales, and service. ${ }^{184}$ In terms of the extent and purposefulness of the defendant's contacts, the Ford cases resemble the cases in which the Court has upheld specific jurisdiction-International Shoe, McGee, Calder, Keeton, and Burger King-and indeed would fall at the easy end of the spectrum. On the issue of minimum contacts, these cases are miles away from World-Wide Volkswagen and Nicastro.

Second, the scope-of-submission aspect of the case-linkage element is satisfied. Ford's contacts with Montana included substantial sales of Ford Explorers; its contacts with Minnesota included substantial sales of Ford Crown Victorias. ${ }^{185}$ These activities are not tangential to the in-state injuries to the plaintiffs from an allegedly defective Explorer in Montana and an allegedly defective Crown Victoria in

183. See Von Mehren \& Trautman, supra note 27, at 1152-53 (emphasis added): A conservative statement of contemporary American thinking on this subject is section 1.03 of the Uniform Interstate and International Procedure Act, approved in 1962 by the Commissioners on Uniform State Laws.

Section 1.03. [Personal Jurisdiction Based upon Conduct.]

(a) A court may exercise personal jurisdiction over a person, who acts directly or by an agent, as to a [cause of action] [claim for relief] arising from the person's ...

(3) causing tortious injury by an act or omission in this state;

(4) causing tortious injury in this state by an act or omission outside this state if he regularly does or solicits business, or engages in any other persistent course of conduct, or derives substantial revenue from goods used or consumed or services rendered, in this state....

The final section of the article actually considers and approves of personal jurisdiction in the particular category of section 1.03(4). See id. at 1176.

184. Ford Motor Co. v. Montana Eighth Judicial Dist. Ct., 443 P.3d 407, 414 (Mont. 2019), cert. granted, No. 19-368, 140 S. Ct. 917 (Jan. 17, 2020); Bandemer v. Ford Motor Co., 931 N.W.2d 744 (Minn. 2019), cert. granted, No. 19-369, 140 S. Ct. 916 (Jan. 17, 2020).

185. Brief of Respondents, supra note 149, at 5-7. 
Minnesota, even if the cars involved in the accidents happen to have been sold elsewhere, originally. When we ask whether the prospect of defending tort suits in the Minnesota and Montana courts for alleged defects in an Explorer or Crown Victoria is something Ford could have reasonably anticipated, the answer is a painfully obvious "yes." When we ask whether Ford, by selling these types of vehicles in these states, may reasonably be deemed to have submitted to these states' authority to adjudicate products liability claims concerning these vehicles, the answer is also "yes." Such adjudications are within the scope of those matters with respect to which Ford has implicitly submitted to the state's authority by purposefully availing itself of those states as a mass manufacturer and seller of automobiles. In this respect, too, the Ford cases resemble the cases in which the Court has upheld specific jurisdiction-International Shoe, McGee, Calder, Keeton, and Burger King - because each case involved a dispute related to the defendant's purposeful contact with the forum state.

Third, the anti-busybody principle is satisfied. Markkaya Gullett, a Montana resident, died in a rollover of a Ford Explorer that occurred on a Montana highway. ${ }^{186}$ Adam Bandemer, a Minnesota resident, suffered injuries in a Minnesota crash of a Ford Crown Victoria when the airbag failed to deploy. ${ }^{187}$ There is no sense in which Montana or Minnesota could be seen as busybody states by making their courts available as forums to adjudicate their claims. They have plenty of reason to have their courts adjudicate these claims for redress arising out of tortious injuries that occurred in state. In this regard, the Ford cases again resemble each case in which the Court upheld specific jurisdiction, including International Shoe, McGee, Calder, Keeton, and Burger King.

Indeed, the Ford cases once again fall at the easy end of the spectrum. In Calder and Keeton, Florida and Ohio arguably would have been more interested forums than California and New Hampshire, whereas in the Ford cases, particularly when one considers joinder of additional parties, it is hard to imagine more appropriate forums than Montana and Minnesota. Turning to the cases in which the Court explicitly or implicitly rejected specific jurisdiction, the busybody problem distinguishes the Ford cases from Helicopteros, Goodyear, Daimler, and most importantly, Bristol-Myers Squibb. Texas lacked sufficient interest in the Peru helicopter crash in Helicopteros; North Carolina lacked sufficient interest in the France bus rollover accident in

186. Id. at 7.

187. Id. at 5. 
Goodyear; California lacked sufficient interest in the Argentina human rights abuses in Daimler; and in Bristol-Myers Squibb, California lacked sufficient interest in the claims of non-Californians who purchased, used, and claimed to have been injured by the defendant's drug in states other than California. ${ }^{188}$ In each of these cases, the states could be accused of being busybodies-meddling in affairs in which they lacked sufficient legitimate interest-and thus violating a defendant's due process rights by exceeding the domain of the state's sovereign power. By contrast, no one could accuse Montana or Minnesota of being busybodies with respect to disputes concerning the Gullett and Bandemer accidents.

One irony of Ford's analysis is that the out-of-state acts on which it focuses-sales in North Dakota and Washington-have become largely irrelevant in the substance of American tort law in many jurisdictions. Put aside that the Ford dealers in North Dakota and Washington state were actually not Ford agents, but independent contractors. Ford seems to imagine that there would be a products liability action in the state of sale. In theory, strict products liability claims may exist against all commercial sellers of a product, including manufacturers, distributors, and retailers. ${ }^{189}$ Yet in recent years, many state legislatures have passed statutes shielding retailers from strict liability claims. Both North Dakota and Washington have such statutes. ${ }^{190}$ One is reminded of Judge Cardozo's famous quip in MacPherson that " $[t]$ he dealer was indeed the one person of whom it might be said with some approach to certainty that by him the car would not be used."191 Likewise, here, the state of the (new car) dealer was a state of which it might be said with certainty that it has no legitimate interest in adjudicating the case (or, at least, a far weaker interest than Minnesota and Montana).

In Bristol-Myers Squibb, the Supreme Court held that although California had personal jurisdiction over the manufacturer for claims by Californians who bought, used, and allegedly suffered injury from Plavix in California, the state did not have personal jurisdiction over

188. Bristol-Myers Squibb Co. v. Superior Ct. of Ca., 137 S. Ct. 1773, 1783 (2017); Daimler AG v. Bauman, 571 U.S. 117, 121-22 (2014); Goodyear Dunlop Tires Operations, S.A. v. Brown, 564 U.S. 915, 919 (2011); Helicopteros Nacionales de Colombia, S.A. v. Hall, 466 U.S. 408, 418-19 (1984).

189. ReSTATEMENT (SECOND) OF TORTS $§ 402 A$ (AM. LAW. INST. 1965).

190. N.D. CEnT. Code ANN. § 28-01.3-04 (1993); WASH. Rev. CodE AnN. § 7.72.040 (West 1991).

191. MacPherson v. Buick Motor Co., 111 N.E. 1050, 1053 (N.Y. 1916). See Alexandra D. Lahav, The New Privity, (Apr. 21, 2020), https://papers.ssrn.com/sol3/papers .cfm?abstract_id=3413349. 
the manufacturer for claims by non-Californians who bought, used, and allegedly suffered injury from Plavix in other states. ${ }^{192}$ Now suppose there had been a Californian plaintiff who took the drug in California and claims to have been harmed by it in California, but who purchased the drug out of state (say, at a pharmacy in Nevada). For purposes of determining whether the plaintiff may sue BMS in California, should this hypothetical plaintiff's claims be placed in the same bucket with the non-Californians over whose claims California lacked power, or rather in the same bucket as the Californians who were permitted to sue at home? Our approach offers a principled basis to reach the intuitively correct answer that the manufacturer's due process rights would not be offended by California's adjudication of the claims of all Californians who claim to have been injured by the drug in California, including our hypothetical plaintiff who happened to have purchased the drug in another state.

\section{COMPARING OUR FRAMEWORK TO ALTERNATIVES}

As mentioned above, courts have taken different approaches to what we call the case-linkage element of specific personal jurisdiction. In particular, they have placed various glosses on the "arising out of or related to" language so often used to describe the linkage requirement. In this Part, we briefly explain why these alternatives are less satisfactory than our approach.

We can begin by considering the non-specific conception of "relatedness" favored by the plaintiffs in the Ford litigation. The plaintiffs (aptly) distinguish their cases from Bristol-Myers Squibb by pointing out that each of the victims was a resident of the forum state and was injured by the defendant's product in the forum state. ${ }^{193}$ Without much by way of further specification, they argue that this is enough to provide the "relatedness" necessary for specific jurisdiction. ${ }^{194}$ The principal shortcoming of this approach is that it is too capacious to provide meaningful guidance. Our framework provides guidance for thinking about relatedness by giving a functional account of the values embedded in the linkage element of case-linked jurisdiction.

Several courts have alternatively ruled that the "arising out of or related to" requirement is satisfied when the defendant's purposeful availment of the forum state functions as a but-for cause of the

192. 137 S. Ct. at 1781-82.

193. Brief of Respondents, supra note 149 , at 20.

194. Id. at $19-20$. 
incident giving rise to the litigation. 195 It is important to see both why the but-for causation requirement is misguided and why it has nevertheless seemed tempting to some courts. We start with a hypothetical:

Ms. Napoli, a Floridian, was a job candidate for a position at Kings Law School in Manhattan. Although she strongly preferred not to live in New York City, she applied for the job because it provided the unusual benefit of a fiveyear, pre-tenure Osla Fellowship for scholars doing research in her areas of interest. The Osla Fellowship is funded by Osla Corporation (Osla), which produces electric cars, among other things. Osla's state of incorporation is Delaware and its principal place of business is Texas.

Napoli flew from Miami to New York to interview for the position. By prior arrangement, Professor Bloom of the Kings Law School met Napoli at Newark International Airport in New Jersey to give her a ride to the school. Bloom's car, as it turns out, was a brand new O-Mobile, a product that Osla exclusively designs, manufactures and sells in Texas, and which Bloom purchased in Texas. While on the New Jersey Turnpike, Bloom's car was struck by another car. Because the O-Mobile's passenger-side airbag malfunctioned, Napoli was seriously injured.

Napoli, who turned down the job and remains a Florida domiciliary, brought a products liability lawsuit against Osla in New York state court.

On the but-for approach to case-linkage, New York courts would have personal jurisdiction over Osla in Napoli's suit against it. Osla's contact with Kings Law School was a purposeful availment of the forum state, and it was a but-for cause of Napoli's injury.

Our point is not merely that the but-for theory gets an intuitively unacceptable result in this hypothetical, although it surely does. More fundamentally, but-for causation fails to capture the idea of caselinked jurisdiction. If its courts were to entertain Napoli's suit against Osla, the State of New York would be asserting power over Osla with respect to a matter in which it has no business, notwithstanding that the defendant's New York contact was a but-for cause of the events giving rise to the litigation. ${ }^{196}$

Our framework takes specific jurisdiction head-on and explains why, in the imagined case of Napoli v. Osla, the New York courts cannot assert personal jurisdiction over Osla. To say that New York has no business hearing the case is, of course, to flag the busybody problem. New York has no particular interest that would support its courts

195. Cf. Brilmayer, supra note 11 , at 11 (proposing a test that asks "whether the defendant's forum contacts in some way contributed to the plaintiff's claim.") (emphasis in original).

196. The problems posed by the but-for causation approach are not solved by adding a proximate cause overlay. If, by its terms, the Osla grant aimed to attract female candidates from Southern States to take junior positions at Kings Law School, both butfor and proximate cause would be satisfied, yet, under existing doctrine, the New York courts would not have personal jurisdiction over Osla in the case of Napoli v. Osla. 
haling Osla before them. The accident in question did not happen in New York. No transaction of relevance to the dispute between Napoli and Osla occurred in New York. Napoli is not a New York resident. In contrast to Texas, Florida and perhaps New Jersey, New York has no reason to entertain this suit. Were it to do so, it would be doing so only as a busybody.

But-for causation is not only overinclusive, it is also underinclusive. Consider the Chinese drywall litigation, ${ }^{197}$ highlighted in the amicus brief submitted in the Ford cases by a group of homebuilders. ${ }^{198}$ Thousands of homeowners are suing Taishan Gypsum Company (Taishan), a Chinese company that supplied defective drywall used to build homes in Florida, Louisiana, and other states. ${ }^{199}$ For simplicity, we address the Florida plaintiffs. The company knew it was supplying drywall to be used in many states including Florida, and it had many actual contacts in Florida, including some purposeful availments it sold some drywall sheets directly to Florida distributors of building materials, and shipped thousands of sheets explicitly to be delivered in Pensacola, Florida). ${ }^{200}$ Nonetheless, the company argued that even where a Florida plaintiff's home had been built with defective Taishan drywall sheets, specific personal jurisdiction would be lacking if those particular sheets came to the builders who built the home with materials supplied by a distributor in a state other than Florida, because in those cases the but-for causation standard is not met.201 The absurd result-according to which a foreign corporation might avoid statecourt jurisdiction for torts committed against state residentsdemonstrates the inaptness of the but-for test. There are purposeful contacts by the defendant with the forum state; these contacts are related to the matter at hand; and courts in Florida would not be meddlers or busybodies in adjudicating these cases.

Finally, we compare our approach to the proximate-causation rendition of case-linkage that has been expressly adopted by some courts. The underinclusiveness of but-for causation - as illustrated in the Chinese drywall cases and explained above-already entails that a proximate cause standard must also fail. Nonetheless, it is

197. In re Chinese-Manufactured Drywall Prods. Liab. Litig., 753 F.3d 521 (5th Cir. 2014); In re Chinese-Manufactured Drywall Prods. Liab. Litig., 742 F.3d 576 (5th Cir. 2014).

198. Brief of the Nat'l Ass'n of Home Builders as Amicus Curiae in Support of Respondents, supra note 146, at 11-14.

199. In re Chinese-Manufactured Drywall Prods. Liab. Litig., 753 F.3d at 526-27.

200. Id. at 536-38.

201. Id. at 543 . 
impossible to resist offering a few more words about why it is especially misguided to suppose that "proximate cause" should be the lodestar of specific personal jurisdiction law.

Is it really plausible, as Ford suggests, that combining proximate cause concepts with specific jurisdiction concepts promises clarity? Even back in 1934, the American Law Institute was so exasperated with "proximate cause" that it excluded the term from the blackletter of the First Torts Restatement. It hoped instead that the term "legal cause" would do better. ${ }^{202}$ Thirty years later, nothing had changed: the Restatement (Second) followed suit. ${ }^{203}$ A decade ago, the Restatement (Third) Reporters correctly concluded that the effort to salvage "proximate cause" by renaming it "legal cause" had failed. ${ }^{204}$ In response, however, they did not return to the traditional usage of proximate cause, but instead tried out a different neologism: "scope of liability." 205 Thus far, there is little reason to think this formulation will fare any better than its predecessors, even as courts cast proximate cause in terms of "foreseeability." 206

Beyond the likelihood that a proximate cause standard would obscure more than it clarifies, there is another irony in Ford's reliance on that concept. It has long been hornbook law that a fact pattern's atypical "manner of harm"-a detour in the causal pathway between a defendant's predicate act and a plaintiff's injury-does not defeat the proximate cause requirement, so long as the plaintiff's injury was foreseeable and was the kind of event as to which the defendant was required to be vigilant. ${ }^{207}$ Design defect law is about Ford's duty to send out into the world vehicles that are sufficiently sound and safe for ordinary use by the consumers it cultivates in its advertising and marketing. The fact that there was an out-of-state sale between Ford's making of the car and its arrival and injuring of a plaintiff in Montana or Minnesota in no way undermines proximate cause, so long as Ford

202. RESTATEMENT OF TORTS $§ 431$ (AM. LAW INST. 1934).

203. RESTATEMENT (SECOND) OF TORTS $§ 431$ (AM. LAW INST. 1965).

204. Restatement (ThiRd) OF TORTS: Liability For PhysicAl \& EMOTIONAl HaRm Ch. 6 note (AM. LAW INST. 2010).

205. Id.

206. Courts famously use "foreseeability" to mean different things in different parts of the common law, see John C.P. Goldberg \& Benjamin C. Zipursky, Vosburg v. Baxendale: Recourse in Tort and Contract, in CIVIL WRONGS AND JUSTICE IN PRIVATE LAW (J. Oberdiek \& P. Miller eds., 2020), and even within the law of negligence. See Benjamin C. Zipursky, Foreseeability in Breach, Duty, and Proximate Cause, 44 WAKE FOREST L. REV. 1247 (2009).

207. Dan B. Dobbs, Paul T. Hayden, \& Ellen M. Bublick, The LaW of TorTs $§ 207$ : FORESEEABILITY: MANNER OF HARM (2d ed. June 2019). 
was aiming for the relevant models of cars to be bought, sold, and used in Montana or Minnesota, which it clearly was.

There is a deeper point about why "proximate cause" does not have a role in the proper analysis of the case-linkage element. Interpretations of "proximate cause" can be roughly divided into "gestalt" and "conceptualistic" approaches. The gestalt approach, typified by Judge Andrews' famous Palsgraf dissent, takes the view that a line on liability must be drawn somewhere for a variety of pragmatic reasons, and interprets "proximate cause" as a façade for judges' or jurors' exercise of this gestalt pragmatic judgment. ${ }^{208}$ No such approach can aid the causes of clarity or certainty. Conceptualistic versions of proximate cause-foreseeability, scope of risk, and the like-deem proximate cause to have an analytic structure that aims to capture when a relationship between what made the defendant's conduct wrongful, on the one hand, and the injury that actually occurred, on the other, is of the right sort to sustain liability. ${ }^{209}$ These conceptualistic accounts also will not help clarify specific personal jurisdiction because the minimum contacts that provide the starting point for jurisdiction are not typically wrongful in any way. Indeed, a great deal of personal jurisdiction law-from International Shoe to Burger King and beyondhas nothing to do with torts or wrongful contacts at all. In sum, conceptualistic versions of proximate cause can get no foothold in this area of the law, while gestalt approaches promise only obscurity.

Invocations of "proximate cause" in the context of jurisdiction are an indirect or analogical way of identifying considerations that can and should be addressed directly. Notions of proximate cause appear superficially relevant to discussions of personal jurisdiction because they refer generally to the idea that there must be the right sort of connection between two things in order for a legal consequence to follow. In the law of negligence, for example, the proximate cause requirement insists that the defendant's careless conduct connect to the plaintiff's injury in a non-haphazard way before liability will attach. With respect to specific personal jurisdiction, the relevant connection, as noted, is not between a wrongful act and an injury, but between the defendant's forum contacts and the events giving rise to the plaintiff's

208. Palsgraf v. Long Island R.R. Co., 162 N.E. 99, 103 (N.Y. 1928) (Andrews, J., dissenting) ('What we do mean by the word 'proximate' is that, because of convenience, of public policy, of a rough sense of justice, the law arbitrarily declines to trace a series of events beyond a certain point. This is not logic. It is practical politics.").

209. See, e.g., RESTATEMENT (ThIRD) OF TORTS: LIABILITY FOR PHYSICAL \& EMOTIONAL HARM $\S 29 \mathrm{cmt}$. d (AM. LAW. INST. 2010) ("Central to the limitation of liability of this Section is the idea that an actor should be held liable only for harm that was among the potential harms - the risks-that made the actor's conduct tortious."). 
claim. For this purpose, the right kind of connection exists so long as the suit concerns a matter within the scope of the defendant's submission to the state's power and so long as the state is not exceeding its legitimate authority. To refer to this standard as a "proximate cause" test adds nothing by way of clarity. Quite the opposite, it only generates confusion and counterintuitive results, including the result under which Ford avoids being subject to products liability claims in a state where it regularly sells the product in question and where the product allegedly malfunctioned causing injury to a state resident, merely because the particular item at issue happened to have first been sold in a different state.

\section{CONCLUSION}

Over the past decade, the Supreme Court has told courts to get serious about personal jurisdiction, and it has drawn a sharp distinction between all-purpose (or general) jurisdiction and case-linked (or specific) jurisdiction. ${ }^{210}$ But the Court has not explained clearly how to analyze the required case-linkage for the latter. This essay fills that gap.

When wrestling with the question of what sort of linkage is required, the temptation to grab at some notion of causation is understandable. But causation does not capture how case-linkage matters for personal jurisdiction. Personal jurisdiction, at the constitutional level, concerns the defendant's due process right not to be subject to the adjudicatory power of a state unless: (a) the dispute falls within the scope of a defendant's submission to state authority and (b) the exercise of power falls within the limits of the state's legitimate authority. These two aspects both bear on the court's jurisdiction because the case-linkage element of specific jurisdiction concerns the limits of a sovereign's adjudicatory authority over a particular defendant and in a particular case. Although the combination of these ideas does indeed delimit specific jurisdiction based on case-linkage in the way suggested by the Court's holdings, neither one is about causation.

First, case-linkage requires a court to consider the scope of the defendant's submission to state authority. Submission to state power not only explains the minimum contacts requirement, it also bears on the case-linkage element of specific jurisdiction. As a matter of general jurisdiction, defendants are considered to have submitted to a state's all-purpose adjudicatory power if they have made the state their home (domicile for an individual, or home state such as state of

210. Bristol-Myers Squibb Co. v. Superior Ct. of Ca., 137 S. Ct. 1773 (2017). 
incorporation or headquarters for a corporation). ${ }^{211}$ For specific jurisdiction, the case must be appropriately linked to the defendant's contacts with the forum state. Thus, even if a defendant has had purposeful contacts with the forum state, the state lacks specific jurisdiction over the defendant if the claims are unrelated to the defendant's purposeful contacts.

But the scope-of-submission aspect of the case-linkage element-important as it is-is not the whole story. In particular, it cannot explain the result in Bristol-Myers Squibb. The point of Bristol-Myers Squibb is that even though the manufacturer had purposeful contacts with California including massive sales of Plavix in the state, and even though every nationwide Plavix product liability claim "related to" those contacts, the case-linkage element failed because California courts were not permitted to meddle in affairs beyond the state's legitimate reach. The Supreme Court saw the California court as a busybody. The California court presumed to adjudicate product liability claims against an out-of-state company by non-Californians whose claims arose entirely outside of California, and that, according to the Supreme Court, went too far. ${ }^{212}$ Case-linkage requires, in addition to satisfying the scope-of-submission principle, that the state not be a busybody.

The Supreme Court, in the Ford cases, has been presented with a perfect opportunity to clarify the case-linkage element. It should see that the right result-both as a matter of the defendant's due process rights and as a matter of permitting a sensible allocation of adjudicatory authority -is that Montana's courts have power to adjudicate a wrongful death claim against Ford that arose out of a crash of a Ford vehicle in Montana, and Minnesota's courts have power to adjudicate a personal injury claim against Ford that arose out of a crash of a Ford vehicle in Minnesota. It should reach that result, and simultaneously provide guidance to lower courts, by explaining what case-linked jurisdiction requires. As we have explained, case-linked jurisdiction requires the establishment of two elements-minimum contacts and case-linkage-and the case-linkage element itself requires satisfaction of two constraints-the scope-of-submission principle and the anti-busybody principle.

211. Daimler AG v. Bauman, 571 U.S. 117, 137, 139 n.19 (2014).

212. Bristol-Myers Squibb Co., 137 S. Ct. at 1781. 